\title{
Propylsulfonic acid functionalized mesoporous silica catalysts for esterification of fatty acids
}

Sirima Jeenpadiphat, Emma Björk, Magnus Odén and Duangamol Nuntasri Tungasmita

\author{
Linköping University Post Print
}

\section{Tweet}

N.B.: When citing this work, cite the original article.

Original Publication:

Sirima Jeenpadiphat, Emma Björk, Magnus Odén and Duangamol Nuntasri Tungasmita, Propylsulfonic acid functionalized mesoporous silica catalysts for esterification of fatty acids, 2015, Journal of Molecular Catalysis A: Chemical, (410), 253-259.

http://dx.doi.org/10.1016/j.molcata.2015.10.002

Copyright: Elsevier

\section{http://www.elsevier.com/}

Postprint available at: Linköping University Electronic Press

http://urn.kb.se/resolve?urn=urn:nbn:se:liu:diva-123508 
Propyl sulfonic acid functionalized mesoporous silica catalysts for esterification of fatty acids

Sirima Jeenpadiphat ${ }^{\mathrm{a}}$, Emma M. Björk ${ }^{\mathrm{b}}$, Magnus Odén ${ }^{\mathrm{b}}$, Duangamol Nuntasri Tungasmita ${ }^{\mathrm{a}, *}$ ${ }^{\mathrm{a}}$ Materials Chemistry and Catalysis Research Unit, Department of Chemistry, Faculty of Science, Chulalongkorn University, 254 Phayathai Road, Bangkok 10330, Thailand ${ }^{\mathrm{b}}$ Nanostructured Materials, Department of Physics, Chemistry and Biology, Linköping University, SE-58183, Sweden

* Corresponding author. Tel.: +66 2187622; Fax: +66 22541309.

E-mail address: duangamol.n@chula.ac.th (D.N. Tungasmita). 


\section{ABSTRACT}

The catalytic properties of three types of mesoporous silica SBA-15 (rope, rod and fiber), with $9.2 \mathrm{~nm}$ or $12.1 \mathrm{~nm}$ large mesopores, were examined with respect to their morphology and pore size. Commercially available Amberlyst-15 and the small pore sized MCM-41 were used for comparison. The catalysts were prepared by functionalization of the silica supports with propyl sulfonic acid $\left(\mathrm{Pr}_{-} \mathrm{SO}_{3} \mathrm{H}\right)$ using post-synthesis grafting with 3-mercaptopropyltrimethoxysilane as a propyl-thiol precursor. All materials remained in a well-ordered hexagonal mesoporous structure after $\mathrm{Pr}-\mathrm{SO}_{3} \mathrm{H}$ functionalization. The performance of the $\mathrm{Pr}-\mathrm{SO}_{3} \mathrm{H}$-functionalized mesoporous silicas was evaluated in terms of their catalytic activity in the esterification of oleic acid with short (methanol) and long (glycerol) chain alcohols, i.e. to test the effect of the pore size on the substrate conversion and product yield. The synthesized catalysts were highly active and the product composition could be tuned by selective choice of the mesopore size. The Pr$\mathrm{SO}_{3} \mathrm{H}$-functionalized rope-shaped SBA-15 gave the highest catalytic activity (in terms of the highest methyl oleate and triglyceride yields and oleic acid conversion level), which was higher than that obtained with the commercial Amberlyst-15 catalyst. A high acid amount, large specific surface area and a suitable pore size are the likely reasons for the high yield gained by Pr-SO ${ }_{3} \mathrm{H}$-functionalized rope-shaped SBA-15 silica.

Keywords:

Mesoporous silica

Acid functionalization

Esterification

Fatty acid

Glycerol 


\section{Introduction}

In order to optimize the performance of mesoporous silica in important applications, such as catalysis, separation, adsorption and ion-exchange, new synthetic chemicals have been introduced into their composition to alter their properties [1]. Recently, several new types of large-pore mesoporous silica materials, such as SBA-15, have been reported [2, 3], where the material's structure and texture, especially the acidic sites, affect its catalytic properties [4].

The use of mesoporous silica SBA-15 as a catalyst was selected for this study because of its well-ordered hexagonal pore structure, high surface area $\left(690-1040 \mathrm{~m}^{2} / \mathrm{g}\right)$ and large-pore diameter (5-30 nm) [5-7]. Different SBA-15 materials exhibit variations in their surface area, pore size and wall thickness, which makes them suitable for different applications [8]. The use of swelling alkane agents, such as hexane and dodecane, in the low temperature synthesis of SBA-15 [9-14] yielded materials with pore sizes that varied from 9.7-15.7 $\mathrm{nm}$ depending on the alkane chain length [8]. Different morphologies (fiber, platelet, rod and film) of mesoporous silica can be prepared by varying the reaction conditions during their synthesis [15-20] or by the addition of $\mathrm{KCl}$ or $\mathrm{NH}_{4} \mathrm{~F}$ salts [21-23].

Esterification is an acid-catalyzed reaction [24], and so to optimize the reaction different types of acid functional groups have been incorporated into the framework of mesoporous silica materials in order to increase their acidity [25]. The improvement in the catalytic activity and selectivity in the esterification of glycerol with fatty acids by the incorporation of alkyl or phenyl groups in combination with sulfonic groups in mesoporous silica is one recently reported example of organo-sulfonic functionalization [24, 26]. In addition, organic-inorganic hybrid silicas synthesized by supramolecular assembly have received increasing attention because of their high surface area, flexible pore size and potential for controlling catalytic functionalities at a molecular level [27-31]. In this study the potential to use acid-functionalized mesoporous silica materials for the catalysis of esterification in the production of biodiesel and glycerol 
esters was evaluated. The products can be used as alternative fuels, or in the food, pharmaceutical and cosmetic industries. Commonly, esterification is performed using conventional acidic homogeneous catalysts, such as $\mathrm{H}_{2} \mathrm{SO}_{4}$ and $\mathrm{HCl}$, to provide a high conversion level and high yield in a short time, but the catalyst is difficult to remove from the product [24]. Therefore, it would be desirable to perform the esterification with an acidic heterogeneous catalyst and then separate the catalyst from the system to both obtain a clean product and to reuse the catalyst.

In the work described here, post-synthesis grafting of 3-mercaptopropyltrimethoxy silane (MPTMS) into heterogeneous mesoporous silica with 2.0-12.1 nm large pores and various morphologies was performed. The mesoporous silica-propyl sulfonic acid $\left(\mathrm{Pr}-\mathrm{SO}_{3} \mathrm{H}\right)$ catalysts subsequently obtained upon oxidation of the thiol precursors were evaluated for their ability to catalyze the esterification of methanol and glycerol with oleic acids. The synthesized Pr- $\mathrm{SO}_{3} \mathrm{H}$-functionalized silica catalysts were characterized by X-ray powder diffractometry (XRD), physisorption, Fourier transform infrared spectroscopy (FTIR), scanning electron microscopy (SEM), transmission electron microscopy (TEM) and acid-base titration analyses. Finally, the relationships between the acidity, specific surface area, mesopore size and catalytic behavior of the catalyst are discussed.

\section{Experimental}

\subsection{Chemicals}

Tetraethyl orthosilicate (TEOS; Fluka) was used as silica precursor in the synthesis of silica mesoporous material. The tri-block copolymer pluronic $\mathrm{P} 123\left(\mathrm{EO}_{20} \mathrm{PO}_{70} \mathrm{EO}_{20}\right)$ (Aldrich), cetyltrimethylammonium bromide (CTAB; Calbiochem) were used as a template for the synthesis of the mesoporous silica. Hydrochloric acid ( $\mathrm{HCl}$; Merck) was used in the aqueous solution to dissolve the P123 template. Heptane (Sigma-Aldrich) and ammonium fluoride $\left(\mathrm{NH}_{4} \mathrm{~F}\right.$; Fluka) were used as swelling and structure controlling agents in the low temperature 
syntheses. MPTMS (Aldrich) was used as the propyl silane precursor and $30 \mathrm{wt} . \%$ hydrogen peroxide $\left(\mathrm{H}_{2} \mathrm{O}_{2}\right.$; Merck) was used as the oxidizing agent. Methanol (Merck), oleic acid (Aldrich) and glycerol (Merck) were the reactants for the esterification reaction. Finally, commercial Amberlyst-15 in the dry form (Rohm \& Haas, France) was dried in oven at $100{ }^{\circ} \mathrm{C}$ for $24 \mathrm{~h}$ before use. Fume silica (Aldrich) was used as a non-porous silica for comparison with the porous SBA-15 silica.

\subsection{Preparation of the mesoporous materials}

\subsubsection{Rope-shaped SBA-15 (Rp-SBA-15)}

The synthesis of rope-shaped SBA-15 (rp-SBA-15) was modified from the previously reported procedure [5] under hydrothermal conditions. In brief, P123 was dissolved in $2.0 \mathrm{M}$ $\mathrm{HCl}$ solution at room temperature and then TEOS was added to a final molar composition of 1.0 TEOS: 0.0165 P123: $6.95 \mathrm{HCl}: 140 \mathrm{H}_{2} \mathrm{O}$. The solution was kept at $40{ }^{\circ} \mathrm{C}$ with stirring conditions for $24 \mathrm{~h}$, and then transferred to a Teflon-lined autoclave for hydrothermal treatment at $100{ }^{\circ} \mathrm{C}$ for $48 \mathrm{~h}$. The template was removed by calcination at $550{ }^{\circ} \mathrm{C}$ in air for $5 \mathrm{~h}$, and the resulting synthesized rope-shaped mesoporous silica was denoted as rp-SBA-15.

\subsubsection{Rod- and fiber-shaped SBA-15 (rd-SBA-15 and f-SBA-15)}

Mesoporous silica with large pores and rod- or fiber-shaped morphologies were synthesized according to the protocols of Johansson et al. $[18,32]$, where the $\mathrm{P} 123$ and $\mathrm{NH}_{4} \mathrm{~F}$ were dissolved in $\mathrm{HCl}$ solutions. Heptane and TEOS were premixed, added to the micellar solution and stirred at $20{ }^{\circ} \mathrm{C}$ for various times. After stirring, and left static for formation of the rod morphology, the solutions were transferred to Teflon flasks and hydrothermally treated for $24 \mathrm{~h}$ at $100{ }^{\circ} \mathrm{C}$. After filtration, the synthesized materials were collected and calcined at $550{ }^{\circ} \mathrm{C}$ in air for $5 \mathrm{~h}$. The stirring time and $\mathrm{HCl}$ concentration were altered in order to obtain rod- or fiber-shaped morphologies. The rod- and fiber-shaped SBA-15 materials were denoted as rdSBA-15 and f-SBA-15, respectively. 


\subsubsection{MCM-41}

Hexagonal mesoporous silica (MCM-41) was prepared from CTAB and TEOS in base solution as previously reported [33]. The surfactants were removed by calcination at $550{ }^{\circ} \mathrm{C}$ in air for $5 \mathrm{~h}$.

\subsection{Catalyst preparation}

The Pr-SO ${ }_{3} \mathrm{H}$-functionalized silica samples were prepared using a modified postsynthesis grafting method based on the protocol of Raju et al. [34]. A mixture of $3.0 \mathrm{~g}$ of the respective silica sample (rp-SBA-15, rd-SBA-15, f-SBA-15, MCM-41 and fume silica) and 5.3 $\mathrm{g}$ of MPTMS was refluxed in $50 \mathrm{~mL}$ of dry toluene for $6 \mathrm{~h}$ and the obtained solid (SBA-15-Pr$\mathrm{SH})$ was filtered and dried in air. The - $\mathrm{SH}$ groups were converted to $-\mathrm{SO}_{3} \mathrm{H}$ groups by oxidation with 30 wt. $\% \mathrm{H}_{2} \mathrm{O}_{2}$ at $60{ }^{\circ} \mathrm{C}$ for $24 \mathrm{~h}$ and then harvested by filtration and washed with water. The materials were acidified under continuous stirring with $50 \mathrm{~mL}$ of $0.2 \mathrm{M}$ sulfuric acid at room temperature for $2 \mathrm{~h}$, filtered and dried at $100^{\circ} \mathrm{C}$ for $4 \mathrm{~h}$ to obtain the respective rp-SBA15-Pr-SO ${ }_{3} \mathrm{H}$, rd-SBA-15-Pr- $\mathrm{SO}_{3} \mathrm{H}$, f-SBA-15-Pr-SO ${ }_{3} \mathrm{H}, \mathrm{MCM}-41-\mathrm{Pr}_{-} \mathrm{SO}_{3} \mathrm{H}$ and fume silica-Pr$\mathrm{SO}_{3} \mathrm{H}$ samples.

\subsection{Esterification of oleic acid with either methanol or glycerol}

The esterification of oleic acid with either methanol or glycerol was performed in a 100$\mathrm{mL}$ round-bottom flask equipped with a magnetic stirrer and a water-cooled condenser. The oleic acid and methanol esterification was performed with a 1:9 molar ratio of oleic acid: methanol at $60^{\circ} \mathrm{C}$, whereas the esterification of oleic acid and glycerol was carried out with a 6:1 molar ratio of oleic acid: glycerol at $110^{\circ} \mathrm{C}$. The reaction time was varied in the range of 15-180 min for methanol or 15-1440 min for glycerol with $0.5 \%$ (w/w) of catalyst (based on the reactant mass). After completion of the reaction, the used catalyst was separated from the liquid phase by centrifugation. 


\subsection{Characterization}

$\mathrm{X}$-ray diffractograms of the catalysts were collected with $\mathrm{Cu} \mathrm{K} \alpha$ radiation using a Rigaku, Dmax 2200/Ultima ${ }^{+}$diffractometer equipped with a monochromator. The unit cell parameter was determined from the peaks in the diffractograms. Nitrogen sorption measurements were performed on a BEL Japan BELSORP-mini 28SP adsorptometer. The specific surface area was calculated using the BET (Brunauer, Emmett and Teller) method for the relative pressure range of $0.1-0.2$, while the pore size distribution and total pore volume were calculated from the BJH (Barret-Joyner-Halender) method. Fourier transform infrared spectroscopy (FTIR) was performed in the range of $400-4000 \mathrm{~cm}^{-1}$ with a $4 \mathrm{~cm}^{-1}$ resolution on a Nicolet 6700 instrument. Prior to the FTIR measurement, the powder samples were vacuumdried at $100{ }^{\circ} \mathrm{C}$ for $30 \mathrm{~min}$ and embedded in a $\mathrm{KBr}$ pellet. The morphology and size of the anhydrous catalyst particles were determined by field emission SEM (FE-SEM) using a JEOL JSM-7001F instrument. In addition, the pore structure of the four silica morphologies (rd-SBA15, rp-SBA-15, f-SBA-15 and MCM-41) and their $\mathrm{Pr}_{-} \mathrm{SO}_{3} \mathrm{H}-$ functionalized derivatives were investigated by TEM using a JEOL JEM-2100 instrument. The acid group level (as $\mathrm{OH}^{-}$ neutralization capacity) of the functionalized mesoporous silica was quantified by standard acid-base titration, where a known exact mass $(\sim 0.05 \mathrm{~g})$ of the sample was added to $15 \mathrm{~mL}$ of 2.0 $\mathrm{M} \mathrm{NaCl}$ solution and allowed to equilibrate for $30 \mathrm{~min}$. Then, it was titrated by the dropwise addition of $0.01 \mathrm{M} \mathrm{NaOH}(\mathrm{aq})$ [31].

The reaction mixture (supernatant) was analyzed by gas chromatography using a Varian CP-3800 gas chromatograph with a CP-8 column, following the EN 14105:2003 procedure. The methyl oleate yield or oleic acid conversion and the mono-, di- and tri-glyceride (MG, DG and TG, respectively) yields were calculated based on the eicosane internal standard, and reported as the mean \pm 1 SD from the independent repeats. 


\section{Results and discussion}

\subsection{Characterization of catalysts}

Small angle X-ray diffractograms of the $\mathrm{Pr}_{-} \mathrm{SO}_{3} \mathrm{H}$-functionalized mesoporous materials are shown in Fig. 1. All the different shaped SBA-15 samples showed three characteristic peaks, which correspond to the 100,110 and 200 preferred orientations, respectively. However, the positions of the diffraction peaks differed between each sample. For the untreated materials, the rd-SBA-15 had the largest unit cell followed by f-SBA-15, rp-SBA-15 and MCM-41, respectively. Comparing the $\mathrm{Pr}-\mathrm{SO}_{3} \mathrm{H}$-functionalized mesoporous silica samples (rp-SBA-15Pr- $\mathrm{SO}_{3} \mathrm{H}$, rd-SBA-15-Pr-SO ${ }_{3} \mathrm{H}$, f-SBA-15-Pr-SO ${ }_{3} \mathrm{H}$ and $\mathrm{MCM}-41-\mathrm{Pr}_{-} \mathrm{SO}_{3} \mathrm{H}$ ) with their respective parent samples (rp-SBA-15, rd-SBA-15, f-SBA-15 and MCM-41), the diffraction peaks of the Pr-SO 3 H-functionalized SBA-15 materials were slightly shifted towards higher diffraction angles. Thus, the lattice parameters were decreased.

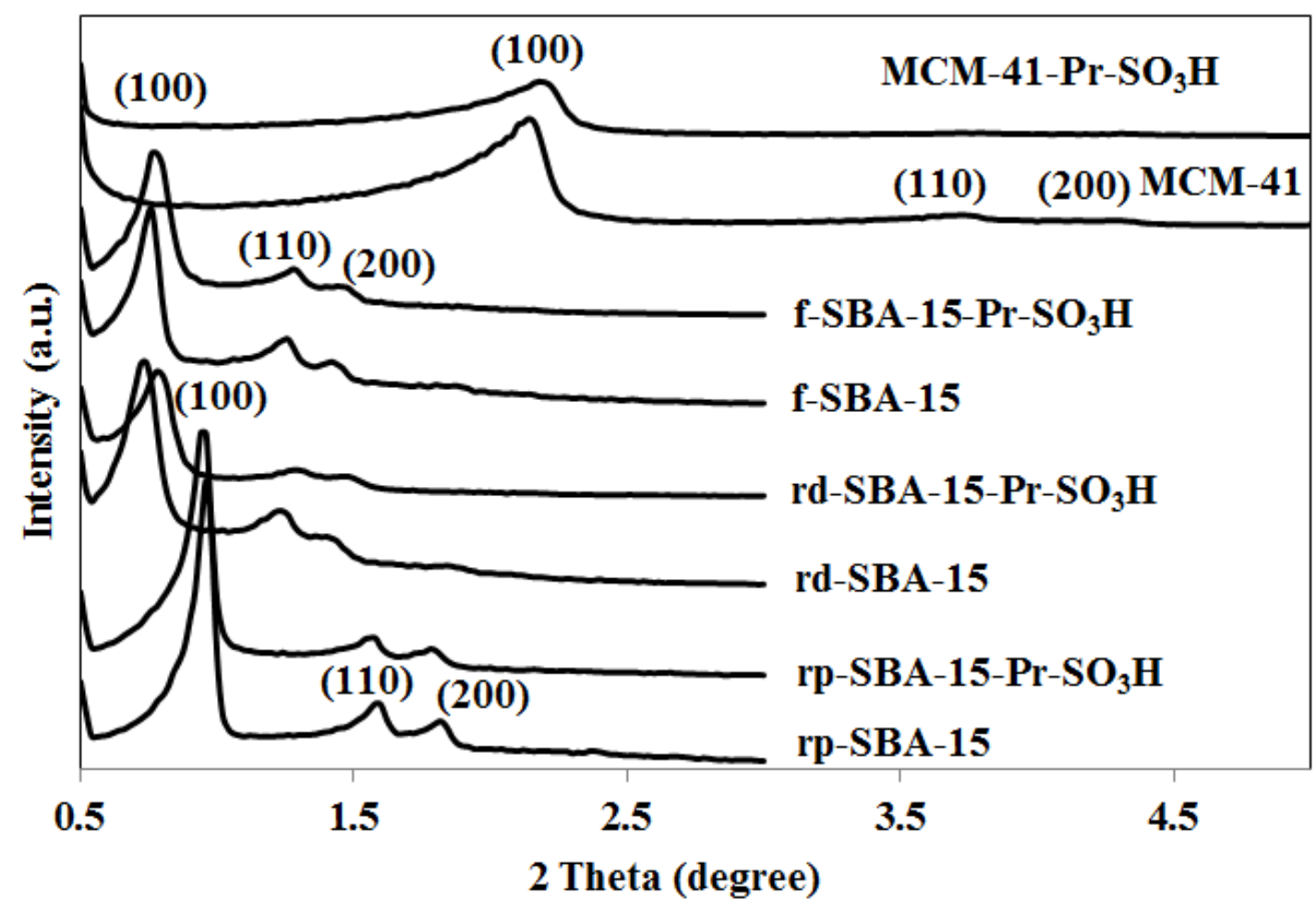

Fig. 1. Representative XRD patterns of mesoporous silica and propyl sulfonic $\left(\mathrm{Pr}-\mathrm{SO}{ }_{3} \mathrm{H}\right)$ functionalized mesoporous silica samples. 
The specific surface area, total pore volume and pore diameter of the samples were calculated from the $\mathrm{N}_{2}$ adsorption-desorption results using the standard BET method and the BJH equation, respectively, whilst the internal surface area was obtained from the t-plot equation (see Table 1). The rp-SBA-15 was found to have a BET surface area of $874 \mathrm{~m}^{2} / \mathrm{g}$, with an internal surface area as large as $820 \mathrm{~m}^{2} / \mathrm{g}$ and a pore diameter of $9.2 \mathrm{~nm}$. After post-synthesis functionalization, rp-SBA-15-Pr-SO ${ }_{3} \mathrm{H}$ had a BET surface area of $733 \mathrm{~m}^{2} / \mathrm{g}$, with an internal surface area of $681 \mathrm{~m}^{2} / \mathrm{g}$ and a pore diameter of $8.0 \mathrm{~nm}$, some 1.2-fold smaller than those of the parent rp-SBA-15 material. The rd-SBA-15, f-SBA-15 and MCM-41 materials plus their Pr$\mathrm{SO}_{3} \mathrm{H}$-functionalized derivatives showed a similar trend, with a smaller BET surface area (1.19to 1.37 -fold), internal surface area (1.21- to 1.40 -fold) and average pore diameter (1.15- to 1.20fold) than that of their respective parent materials.

With respect to the pore size of the materials, rd-SBA-15 and f-SBA-15 had the largest pore sizes of $\sim 12.1 \mathrm{~nm}$, followed by rp-SBA-15 $(9.2 \mathrm{~nm})$ and MCM-41 $(2.4 \mathrm{~nm})$. This is expected because of the alkane solvent effect [35]. The decrease in the BET surface area, internal surface area and pore size after $\mathrm{Pr}_{-} \mathrm{SO}_{3} \mathrm{H}$ functionalization indicated that the implemented preparation conditions allowed the organo-sulfonic acid group to be incorporated both into and on the mesoporous structure and surface at the same time. This was also indicated by the increasing wall thickness after $\mathrm{Pr}-\mathrm{SO}_{3} \mathrm{H}$ functionalization (Table 1). 


\section{Table 1}

Physicochemical and textural properties of the propyl sulfonic acid $\left(\mathrm{Pr}-\mathrm{SO}_{3} \mathrm{H}\right)$-functionalized samples.

\begin{tabular}{|c|c|c|c|c|c|c|c|c|c|}
\hline$\overline{\text { Catalyst }}$ & $\begin{array}{l}\text { BET surface } \\
\text { area }^{\text {a }} \\
\left(\mathrm{m}^{2} / \mathrm{g}\right)\end{array}$ & $\begin{array}{l}\text { Internal } \\
\text { surface area } \\
\left(\mathrm{m}^{2} / \mathrm{g}\right)\end{array}$ & $\begin{array}{l}\text { External } \\
\text { surface area } \\
\left(\mathrm{m}^{2} / \mathrm{g}\right)\end{array}$ & $\begin{array}{l}\text { Internal/ } \\
\text { External }\end{array}$ & $\begin{array}{l}\text { Total pore } \\
\text { volume } \\
\left(\mathrm{cm}^{3} / \mathrm{g}\right)\end{array}$ & $\begin{array}{l}\text { Average pore } \\
\text { diameter }{ }^{\mathrm{c}} \\
(\mathrm{nm})\end{array}$ & $\begin{array}{l}\mathrm{a}_{0}{ }^{\mathrm{d}} \\
(\mathrm{nm})\end{array}$ & $\begin{array}{l}\text { Wall } \\
\text { thickness }^{\mathrm{d}} \\
(\mathrm{nm})\end{array}$ & $\begin{array}{l}\text { Acid } \\
\text { amount }^{\mathrm{e}} \\
(\mathrm{mmol} / \mathrm{g})\end{array}$ \\
\hline rp-SBA-15-Pr- $\mathrm{SO}_{3} \mathrm{H}$ & 733 & 681 & 32 & 21.3 & 1.04 & 8.0 & 10.8 & 2.8 & 1.58 \\
\hline rd-SBA-15-Pr-SO ${ }_{3} \mathrm{H}$ & 303 & 187 & 143 & 1.3 & 1.15 & 10.5 & 13.1 & 2.6 & 1.54 \\
\hline f-SBA-15 & 462 & 379 & 104 & 3.6 & 1.21 & 12.1 & 13.5 & 1.4 & 0.58 \\
\hline f-SBA-15-Pr-SO ${ }_{3} \mathrm{H}$ & 387 & 313 & 93 & 3.4 & 1.07 & 10.5 & 13.1 & 2.6 & 1.28 \\
\hline MCM-41 & 954 & 918 & 40 & 23.0 & 0.89 & 2.4 & 4.7 & 2.3 & 0.54 \\
\hline Fume silica-Pr-SO $\mathrm{S}_{3} \mathrm{H}$ & 158 & - & - & - & - & - & - & - & 0.15 \\
\hline
\end{tabular}

${ }^{\mathrm{a} C a l c u l a t e d}$ by the BET method

${ }^{\mathrm{b}}$ Internal surface area $=($ total surface area $($ from $t$-plot $))-($ external surface area $($ from $t$-plot $))$

${ }^{\mathrm{c}}$ Calculated by the BJH method

${ }^{\mathrm{d}}$ Wall thickness $=\left(\mathrm{a}_{0}\right)-($ pore diameter $)$, where $\mathrm{a}_{0}=2 \times d_{(100)} / \sqrt{3}, d_{(100)}=d$-spacing of the $(100)$ reflection from the XRD analysis 
${ }^{\mathrm{e}}$ Acid amount obtained by acid-base titration

${ }^{\mathrm{f}}$ Data from the suppliers (Rohm \& Haas, France) 
Furthermore, from the XRD and nitrogen adsorption analyses, it was seen that each mesoporous parent sample had a different wall thickness, resulting in different thermal stabilities. This is the effect of the different synthesis conditions where the temperature, $\mathrm{NH}_{4} \mathrm{~F}$ and heptane affected the solubility of the surfactants, resulting in the large pore size for the rdSBA-15 and f-SBA-15 [21].

The nitrogen adsorption-desorption isotherms (Fig. 2) for the three types of parent mesoporous SBA-15 silica and their respective $\mathrm{Pr}-\mathrm{SO}_{3} \mathrm{H}$-functionalized derivatives exhibited characteristic type IV isotherms, with a type 1 hysteresis loop at relative pressures of around 0.6-0.8, which is typical for this type of material $[36,37]$. The rd-SBA-15 and f-SBA-15 samples exhibited a hysteresis loop at higher relative pressures than rp-SBA-15 and MCM-41, indicating the larger pore size of rd-SBA-15 and f-SBA-15 [38]. The position of the adsorption branch is related to the pore size distribution; in particular, the capillary condensation pressure is an increasing function of the pore diameter. The capillary condensation of the rp-SBA-15 and its functionalized derivative occurred at a lower relative pressure $\left(p / p_{0}=0.7\right)$ than that for rdSBA-15, f-SBA-15 and their functionalized samples $\left(p^{\prime} p_{0}=0.8\right)$, indicating that rp-SBA-15 and its functionalized derivative have a smaller pore diameter than rd- and f-SBA-15. 


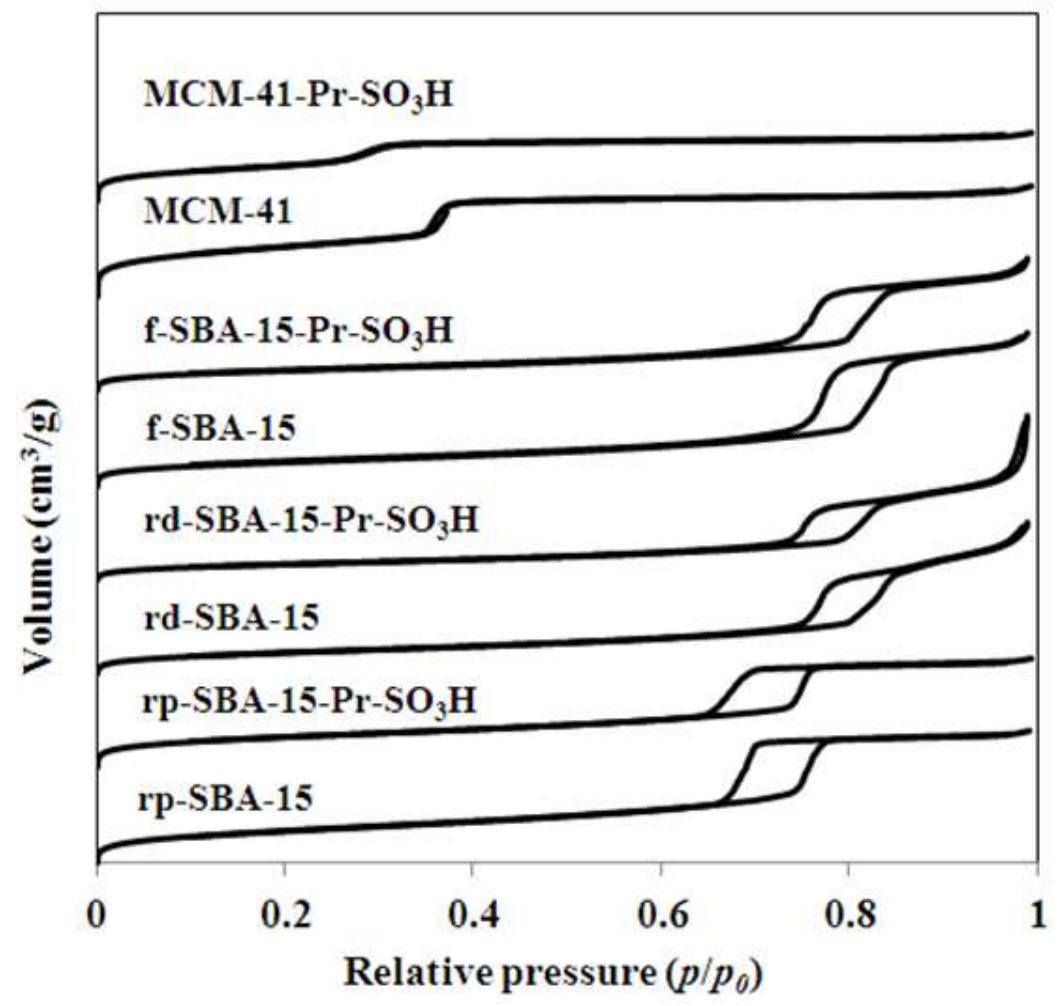

Fig. 2. Representative $\mathrm{N}_{2}$ adsorption/desorption isotherms of mesoporous silica and the propyl sulfonic $\left(\mathrm{Pr}_{-} \mathrm{SO}_{3} \mathrm{H}\right)$-functionalized mesoporous silica samples.

The net acid site values of the parent mesoporous silicas were relatively low (from 0.24 $\mathrm{mmol} / \mathrm{g}$ for $\mathrm{rp}-\mathrm{SBA}-15$ to $0.58 \mathrm{mmol} / \mathrm{g}$ for $\mathrm{f}-\mathrm{SBA}-15)$, but were significantly increased (2.2- to

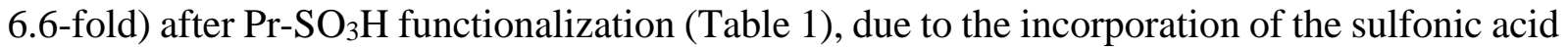
groups. However, after $\mathrm{Pr}_{-} \mathrm{SO}_{3} \mathrm{H}$ functionalization, the amount of acid sites was still $\sim$ two-fold lower than that of the commercial Amberlyst-15 catalyst.

Figure 3 shows the FTIR spectra of the different mesoporous silica SBA-15 and Pr$\mathrm{SO}_{3} \mathrm{H}$-functionalized SBA-15 samples. The four characteristic peaks of tetrahedral silicon oxide samples were seen at $467 \mathrm{~cm}^{-1}$ (Si-O-Si and O-Si-O bending vibrations), $800 \mathrm{~cm}^{-1}$ (Si-O-Si, symmetric vibration), $962 \mathrm{~cm}^{-1}$ (Si-O bending vibration) and the large band at $1090 \mathrm{~cm}^{-1}$ (Si-O$\mathrm{Si}$, asymmetric vibrations) $[39,40]$. In addition, all the samples showed the $\mathrm{O}-\mathrm{H}$ bending 
vibration of water at $1640 \mathrm{~cm}^{-1}$. In the functionalized samples, the strongest bands of $-\mathrm{SO}_{3} \mathrm{H}$ groups and S-C stretching of $-\mathrm{CH}_{2} \mathrm{SO}_{3} \mathrm{H}$ groups are the best evidence of the successful grafting of the propyl sulfonic groups. In fact, the $\mathrm{S}=\mathrm{O}$ asymmetric-stretching $\left(\mathrm{SO}_{2}\right)$ vibrational mode is clearly visible at around $1350 \mathrm{~cm}^{-1}$ [41]. In the FTIR spectra of the functionalized samples, the peak at $1350 \mathrm{~cm}^{-1}$ was shifted to a higher frequency $\left(1400 \mathrm{~cm}^{-1}\right)$ and the S-OH stretching vibration of $\mathrm{SO}_{3} \mathrm{H}$ at $840 \mathrm{~cm}^{-1}$ was also observed. Moreover, the $\mathrm{S}-\mathrm{C}$ stretching vibration of the propyl sulfonic groups was detected at $603 \mathrm{~cm}^{-1}$ [41]. These three characteristic peaks of the propyl sulfonic groups did not appear in the pure SBA-15 samples. Thus, from the FTIR results it was concluded that the propyl sulfonic groups were grafted on the surface of the mesoporous silica samples.

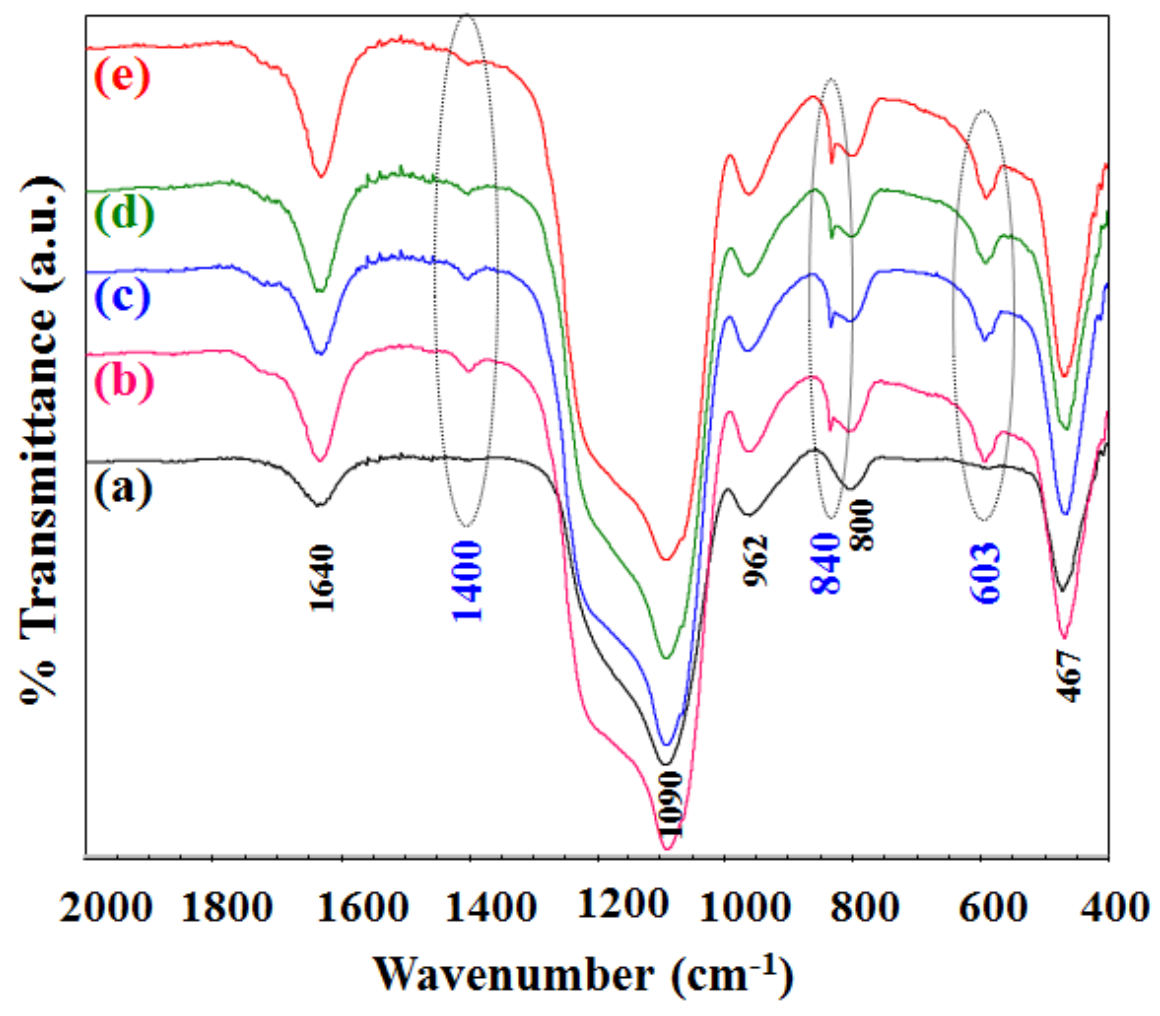


Fig. 3. Representative FTIR spectra of the (a) rp-SBA-15, (b) rp-SBA-15-Pr-SO 3 H, (c) rdSBA-15-Pr-SO ${ }_{3} \mathrm{H}$, (d) f-SBA-15-Pr- $\mathrm{SO}_{3} \mathrm{H}$ and (e) MCM-41-Pr- $\mathrm{SO}_{3} \mathrm{H}$ samples, in the spectral region of $400-2000 \mathrm{~cm}^{-1}$.

The SEM micrographs revealed different anhydrous morphologies for all the samples, as shown in Fig. 4(a)-(d). Rp-SBA-15 (Fig. 4(a)) appeared as a regular dispersion containing small rod-shaped particles that agglomerated to a rope-like structure, whilst rp-SBA-15-Pr-SO $\mathrm{S}_{3} \mathrm{H}$ (not shown) formed a higher aggregation level of small particles with a rope-like structure, somewhat similar to the parent rp-SBA-15. The rd-SBA-15 and its $\mathrm{Pr}_{-} \mathrm{SO}_{3} \mathrm{H}$-functionalized derivative exhibited the formation of the smallest rod-like structures $(\sim 600 \mathrm{~nm}$ long with $80-200 \mathrm{~nm}$ rod diameter), whereas f-SBA-15 and its functionalized derivative showed fiber-like structures. In addition, the size of the rd-SBA-15 particles was smaller than those in the rp- and f-SBA-15 materials. On the other hand, MCM-41 had an ordered rod-like structure of $2.5 \times 0.5 \mu \mathrm{m}$ sized particles, while its functionalized derivative still exhibited the same particle shape but was more aggregated.

The cylindrical pore structure in all the samples was investigated by TEM (Fig. 4(e)(h)), where all the samples showed well-ordered cylindrical channels. From the TEM image of rp-SBA-15-Pr-SO $3 \mathrm{H}$ (Fig. 4(e)), the distance between the pores was estimated to be close to 10 $\mathrm{nm}$ in the case of the SBA-15 samples, which is in agreement with the unit cell parameter derived from the XRD data (Table 1). Likewise, the distance between the mesopore channels of rd-SBA-15-Pr-SO ${ }_{3} \mathrm{H}$ and $\mathrm{f}-\mathrm{SBA}-15-\mathrm{Pr}-\mathrm{SO}_{3} \mathrm{H}$ was larger than that for rp-SBA-15-Pr-SO $\mathrm{S}_{3} \mathrm{H}$ and MCM-41-Pr- $\mathrm{SO}_{3} \mathrm{H}$, which confirmed the results from the physisorption and XRD analyses. 

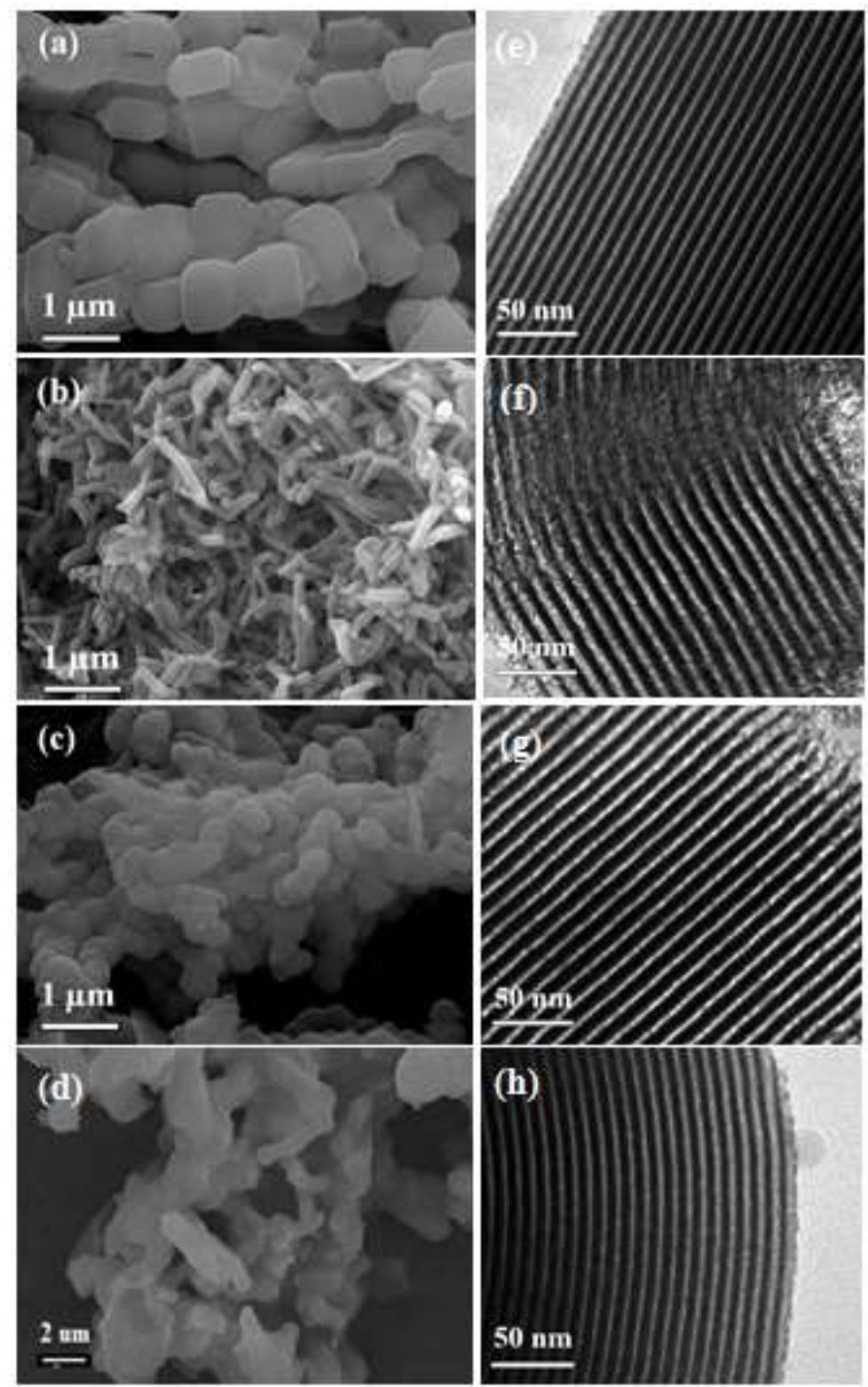

Fig. 4. Representative SEM images (20,000 × magnification) of (a) rp-SBA-15, (b) rd-SBA-15, (c) f-SBA-15, (d) MCM-41 and TEM images of (e) rp-SBA-15-Pr-SO ${ }_{3} \mathrm{H}$, (f) rd-SBA-15-Pr$\mathrm{SO}_{3} \mathrm{H}$, (g) f-SBA-15-Pr-SO ${ }_{3} \mathrm{H}$ and (h) MCM-41-Pr-SO ${ }_{3} \mathrm{H}$.

\subsection{Catalytic activity}

The esterification of a 1:9 molar ratio of oleic acid: methanol mixture at $60{ }^{\circ} \mathrm{C}$ was performed with the prepared catalysts at a $0.5 \mathrm{wt}$. \% catalytic loading, which has previously 
been found to be optimal [42]. The catalytic reaction was evaluated in comparison to two reference reactions; one with the commercial Amberlyst-15 using the same loading level, and one with no catalyst present. The reaction was evaluated over $180 \mathrm{~min}$ during which time the product yield increased with time without evidence of having reached equilibrium or a maximum (Fig. 5). All catalysts displayed some catalytic activity, significantly increasing the methyl oleate (MO) yield obtained compared to when no catalyst was used. The rp-SBA-15-Pr$\mathrm{SO}_{3} \mathrm{H}$ catalyst exhibited the highest $\mathrm{MO}$ yield, in agreement with its highest acid site level and largest specific surface area (Table 1). However, all the $\mathrm{Pr}-\mathrm{SO}_{3} \mathrm{H}$-functionalized mesoporous silica catalysts gave a superior MO yield over that obtained with the commercial Amberlyst-15 catalyst, despite the higher amount of acid sites and larger pore diameter of the commercial catalyst. This is likely to be due to their significantly higher specific surface area and total pore volume.

Furthermore, the fume silica was chosen as non-porous silica (supplementary information (SI), Fig. S1 and Fig. S2) for comparison with porous SBA-15 silica. The result showed that fume silica-Pr- $\mathrm{SO}_{3} \mathrm{H}$ exhibited a $11 \%$ lower $\mathrm{MO}$ yield than the other catalysts, presumably because of its low surface area and acidity. 


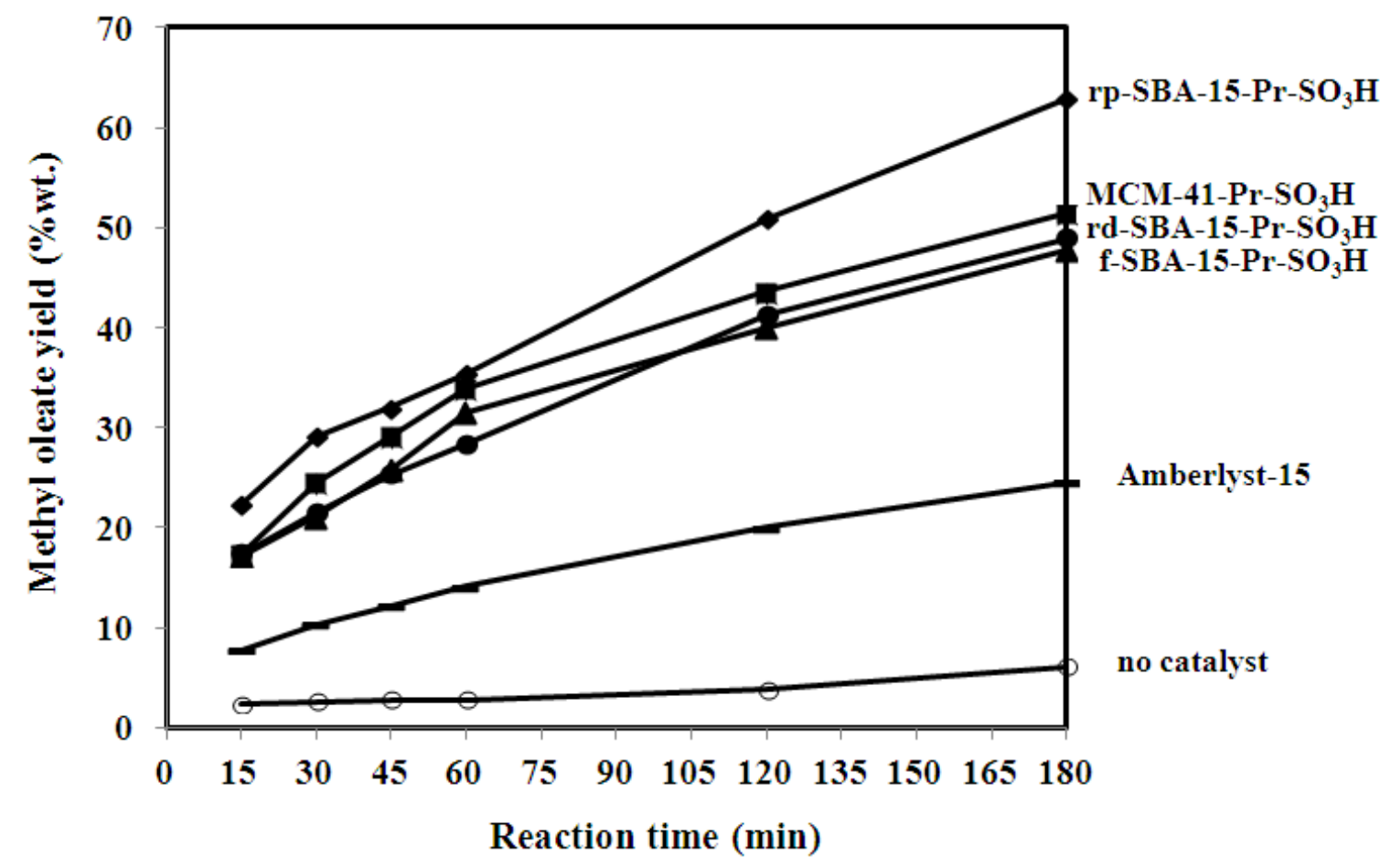

Fig. 5. Time course of the esterification of a $1: 9$ molar ratio of oleic acid: methanol at $60^{\circ} \mathrm{C}$ for 15-180 min with 0.5 wt. \% of the different propyl sulfonic acid $\left(\mathrm{Pr}-\mathrm{SO}_{3} \mathrm{H}\right)$-functionalized mesoporous silica catalysts or the commercial Amberlyst-15 one, compared to that without a catalyst.

The catalytic activity of the $\mathrm{Pr}-\mathrm{SO}_{3} \mathrm{H}$-functionalized materials in the esterification process of oleic acid to glycerol was evaluated since the molecular flow depends on the size and shape of both the catalyst and its substrates. Therefore, the methanol reactant was replaced by the larger glycerol to test the effect of catalytic pore size on the substrate conversion and product yield. The structural size (length $\times$ wide), determined using the HyperChem program, of oleic acid, methanol and glycerol were $1.76 \times 1.27 \mathrm{~nm}^{2}, 0.12 \times 0.12 \mathrm{~nm}^{2}$ and $0.37 \times 0.29 \mathrm{~nm}^{2}$, respectively. Furthermore, the structural size of MO, MG, 1,2-DG and TG products were 1.61 
$\times 1.27 \mathrm{~nm}^{2}, 1.19 \times 0.91 \mathrm{~nm}^{2}, 2.15 \times 1.20 \mathrm{~nm}^{2}$ and $3.94 \times 2.59 \mathrm{~nm}^{2}$, respectively. The TG product was used as the indicator to study the potential effect of the mesopore size.

The oleic acid and glycerol esterification was performed with a 6:1 mole ratio of oleic acid: glycerol over a $5 \mathrm{wt} . \%$ catalyst loading (based on total reactant weight) at $110^{\circ} \mathrm{C}$ for $15-$ 1440 min. The reaction time was found to have a major influence on the obtained conversion level and product yield, where short reaction times (15-30 min) were insufficient to complete the esterification reaction (Table 2). In fact, the esterification of glycerol (a tri-hydroxy alcohol) with oleic acid encompasses multiple sequential esterification reactions involving the oleic acid acyl group protonation and glycerol hydroxyl group attraction to produce the MG followed by esterifying the remaining hydroxyl group to DG and TG.

As the reaction time was extended, the esterification of MG to DG and to TG was increased and the MG yield decreased. This result can be explained by the increased nucleophilic attacks of the remaining hydroxyl groups of the MG moiety on the acid site-oleic acid complex on the catalyst surface. For longer reaction times of 45-60 min, the highest oleic acid conversion level to TG was obtained at about $99 \%$ with the rp-SBA-15-Pr- $\mathrm{SO}_{3} \mathrm{H}$, Amberlyst-15 and f-SBA-15-Pr-SO $3 \mathrm{H}$ catalysts, and at $98.7 \%$ and $91.5 \%$ for the rd-SBA-15$\mathrm{Pr}_{-} \mathrm{SO}_{3} \mathrm{H}$ and $\mathrm{MCM}-41-\mathrm{Pr}-\mathrm{SO}_{3} \mathrm{H}$, respectively. This showed that the reaction can be completed within $60 \mathrm{~min}$, a time at which the equilibrium point of the reaction seemed to be attained, if a highly efficient catalyst was used. However, the TG yield then decreased with increasing reaction time beyond 45-60 min, due to the backward reaction to form the intermediate MG and DGs, and starting material (see example in Table S1). Furthermore, the large pore catalysts (rpSBA-15-Pr- $\mathrm{SO}_{3} \mathrm{H}$, rd-SBA-15-Pr- $\mathrm{SO}_{3} \mathrm{H}, \mathrm{f}-\mathrm{SBA}-15-\mathrm{Pr}_{-} \mathrm{SO}_{3} \mathrm{H}$ and Amberlyst-15) exhibited a higher TG yield than the small pore catalyst (MCM-41-Pr-SO $3 \mathrm{H})$. This result supported that TG products could not be produced in the MCM-41-Pr- $\mathrm{SO}_{3} \mathrm{H}$ pores due to the smaller pore size than 
the TG structure, and so TG is only produced at the external surface of the material. The pore size of the catalyst can hence in part be chosen to select what product should be formed during the reaction. The rp-SBA-15-Pr-SO $\mathrm{S}_{3} \mathrm{H}$ catalyst gave the highest TG yield (64.3\%) after a $60 \mathrm{~min}$ reaction time, which was 2.5-fold higher than the yield with the commercial Amberlyst-15 catalyst. When the catalytic efficiencies of the large pore catalysts were compared, rp-SBA-15Pr-SO $\mathrm{SO}_{3} \mathrm{H}$ showed a higher TG yield compared to rd-SBA-15-Pr- $\mathrm{SO}_{3} \mathrm{H}$ and f-SBA-15-Pr-SO $\mathrm{S}_{3}$. This is presumably due to its higher specific surface area, internal surface area and acid amount. Both the internal surface area and acid amount played a major role in catalytic efficiency. In the first $45 \mathrm{~min}$ of reaction time, the rope- and fiber-shaped catalysts, with their high internal/external surface area ratios, provided a higher oleic conversion and TG yield compared to the rod-shaped catalyst. However, after $45 \mathrm{~min}$ the rod-shaped catalyst continued to increase the esterification reaction, as did the rope-shaped catalyst, which is attributed to their high acidic properties. Furthermore, the fiber-shaped mesoporous catalyst (f-SBA-15-Pr- $\mathrm{SO}_{3} \mathrm{H}$ ) gave a higher TG yield than the rod-shaped catalyst at reaction times of less than 60 min.

The catalytic activity of rp-SBA-15-Pr- $\mathrm{SO}_{3} \mathrm{H}$, Amberlyst-15, f-SBA-15-Pr- $\mathrm{SO}_{3} \mathrm{H}$, rdSBA-15-Pr- $\mathrm{SO}_{3} \mathrm{H}$ and MCM-41-Pr- $\mathrm{SO}_{3} \mathrm{H}$ was also determined from the \% yield of $\mathrm{MG}, \mathrm{DG}$ and TG with respect to the number of acidic active sites, in terms of the turnover number (TON) and turnover frequency (TOF). Here, the highest TON and TOF of 28.4 and $1.89\left(\mathrm{~min}^{-1}\right)$ were obtained with 5 wt.\% of the f-SBA-15- $\mathrm{Pr}_{-} \mathrm{SO}_{3} \mathrm{H}$ catalyst at $15 \mathrm{~min}$ (Table 3). This result indicated that acidic active sites of $\mathrm{f}-\mathrm{SBA}-15-\mathrm{Pr}-\mathrm{SO}_{3} \mathrm{H}$ reacted fast with the reactants and provided the highest net level of products $(\mathrm{MG}+\mathrm{DG}+\mathrm{TG})$. Moreover, this catalyst contained the lowest amount of acid sites when compared with the other catalysts. However, for TG production, the f-SBA-15-Pr- $\mathrm{SO}_{3} \mathrm{H}$ catalyst formed a lower TG yield than that with rp-SBA-15$\mathrm{Pr}-\mathrm{SO}_{3} \mathrm{H}$. 
It should also be noted that the acid amount of the catalyst depends on the number of free silanol groups of the mesoporous parent. In case of the f-SBA-15 parent sample, the acid amount was higher than the rod- and rope-shaped samples, perhaps due to an easier ionexchange capability of protons at the silanol groups. However, after some hydroxyl groups were changed to thiol groups, disulfide linkages may form in the f-SBA-15-Pr-SH structure, generating the less active sulfonic group in the f-SBA-15- $\mathrm{Pr}-\mathrm{SO}_{3} \mathrm{H}$ sample [39]. Therefore, the catalytic performance in esterification reaction depends on both the particle shape and acidity of the mesoporous material. 


\section{Table 2}

The oleic acid conversion level and triglyceride (TG) yield in the esterification of a 6:1 oleic acid: glycerol molar ratio reaction catalyzed by a 5 wt. \% catalyst loading (based on total reactant weight) of propyl sulfonic acid (Pr-SO ${ }_{3} \mathrm{H}$ )-functionalized mesoporous silica or the commercial Amberlyst- 15 catalyst at $110^{\circ} \mathrm{C}$ for up to 1440 min of reaction time.

\begin{tabular}{|c|c|c|c|c|c|c|c|c|c|c|c|c|}
\hline \multirow{3}{*}{$\begin{array}{l}\text { Reaction } \\
\text { time } \\
(\min )\end{array}$} & \multicolumn{12}{|c|}{ Catalyst } \\
\hline & \multicolumn{2}{|c|}{ No catalyst } & \multicolumn{2}{|c|}{ Amberlyst-15 } & \multicolumn{2}{|c|}{ rp-SBA-15-Pr-SO ${ }_{3} \mathrm{H}$} & \multicolumn{2}{|c|}{$\mathrm{f}-\mathrm{SBA}-15-\mathrm{Pr}-\mathrm{SO}_{3} \mathrm{H}$} & \multicolumn{2}{|c|}{ rd-SBA-15-Pr-SO ${ }_{3} \mathrm{H}$} & \multicolumn{2}{|c|}{$\mathrm{MCM}-41-\mathrm{Pr}-\mathrm{SO}_{3} \mathrm{H}$} \\
\hline & $\begin{array}{c}\text { Oleic acid } \\
\text { conversion } \\
(\%)\end{array}$ & $\begin{array}{c}\mathrm{TG} \\
\text { yield } \\
(\%)\end{array}$ & $\begin{array}{c}\text { Oleic acid } \\
\text { conversion } \\
(\%)\end{array}$ & $\begin{array}{c}\mathrm{TG} \\
\text { yield } \\
(\%)\end{array}$ & $\begin{array}{c}\text { Oleic acid } \\
\text { conversion } \\
(\%)\end{array}$ & $\begin{array}{c}\mathrm{TG} \\
\text { yield } \\
(\%)\end{array}$ & $\begin{array}{c}\text { Oleic acid } \\
\text { conversion } \\
(\%)\end{array}$ & $\begin{array}{c}\text { TG } \\
\text { yield } \\
(\%)\end{array}$ & $\begin{array}{c}\text { Oleic acid } \\
\text { conversion } \\
(\%)\end{array}$ & $\begin{array}{c}\text { TG } \\
\text { yield } \\
(\%)\end{array}$ & $\begin{array}{c}\text { Oleic acid } \\
\text { conversion } \\
(\%)\end{array}$ & $\begin{array}{c}\mathrm{TG} \\
\text { yield } \\
(\%)\end{array}$ \\
\hline 15 & - & - & 22.5 & - & 89.1 & 45.4 & 88.0 & 22.9 & 82.5 & 17.4 & 70.2 & - \\
\hline 30 & - & - & 83.3 & 3.1 & 96.6 & 50.7 & 96.6 & 40.7 & 90.4 & 24.8 & 77.3 & 3.9 \\
\hline 45 & - & - & 92.3 & 15.2 & 98.4 & 53.3 & 99.0 & 40.2 & 91.4 & 29.9 & 86.2 & 11.2 \\
\hline 60 & - & - & 99.3 & 25.8 & 99.7 & 64.3 & 64.2 & 34.4 & 98.7 & 34.2 & 91.5 & 13.2 \\
\hline 120 & 9.3 & - & 96.9 & 44.4 & 97.7 & 31.2 & 55.3 & 33.9 & 88.8 & 37.8 & 96.4 & 14.7 \\
\hline 180 & 16.9 & 0.4 & 89.4 & 37.9 & 86.5 & 30.3 & 49.4 & 29.8 & 54.7 & 22.8 & 90.9 & 21.6 \\
\hline 360 & 22.9 & 1.1 & 69.3 & 20.1 & 72.6 & 29.6 & 44.7 & 25.6 & 47.8 & 21.1 & 81.2 & 30.5 \\
\hline 540 & 25.2 & 1.9 & 43.1 & 20.0 & 65.1 & 28.9 & 47.4 & 24.8 & 44.6 & 20.9 & 50.4 & 15.7 \\
\hline 720 & 32.9 & 2.5 & 40.2 & 17.9 & 61.4 & 27.3 & 33.8 & 15.3 & 40.7 & 19.7 & 46.4 & 13.8 \\
\hline 1440 & 72.8 & 14.3 & 31.5 & 11.3 & 60.5 & 27.1 & 27.5 & 10.6 & 36.9 & 18.1 & 40.0 & 11.3 \\
\hline
\end{tabular}

Data are shown as the mean $\pm 1 \mathrm{SD}$, derived from three independent repeats. 


\section{Table 3}

The turnover number (TON) and turnover frequency (TOF) from the esterification of a 6:1 oleic acid: glycerol molar ratio reaction catalyzed by a 5 wt. \% catalyst loading (based on

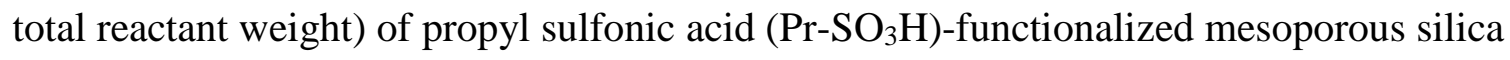
or the commercial Amberlyst- 15 catalyst at $110^{\circ} \mathrm{C}$ for up to 1440 min of reaction time.

\begin{tabular}{|c|c|c|c|c|c|c|c|c|c|c|}
\hline \multirow{4}{*}{$\begin{array}{l}\text { Reaction } \\
\text { time } \\
(\text { min) }\end{array}$} & \multicolumn{10}{|c|}{ Catalyst } \\
\hline & \multicolumn{2}{|c|}{ Amberlyst-15 } & \multicolumn{2}{|c|}{ rp-SBA-15-Pr- $\mathrm{SO}_{3} \mathrm{H}$} & \multicolumn{2}{|c|}{ f-SBA-15-Pr-SO ${ }_{3} \mathrm{H}$} & \multicolumn{2}{|c|}{ rd-SBA-15-Pr- $\mathrm{SO}_{3} \mathrm{H}$} & \multicolumn{2}{|c|}{ MCM-41-Pr-SO ${ }_{3} \mathrm{H}$} \\
\hline & TON & TOF & TON & TOF & TON & TOF & TON & TOF & TON & TOF \\
\hline & & $\left(\min ^{-1}\right)$ & & $\left(\min ^{-1}\right)$ & & $\left(\min ^{-1}\right)$ & & $\left(\min ^{-1}\right)$ & & $\left(\min ^{-1}\right)$ \\
\hline 15 & 3.9 & 0.26 & 19.0 & 1.26 & 28.4 & 1.89 & 24.1 & 1.61 & 23.4 & 1.56 \\
\hline 30 & 11.4 & 0.38 & 19.7 & 0.66 & 24.9 & 0.83 & 23.3 & 0.78 & 24.6 & 0.82 \\
\hline 45 & 10.5 & 0.23 & 19.5 & 0.43 & 23.7 & 0.53 & 21.7 & 0.48 & 26.1 & 0.58 \\
\hline 60 & 10.4 & 0.17 & 17.3 & 0.29 & 15.4 & 0.26 & 22.9 & 0.38 & 26.9 & 0.45 \\
\hline 120 & 9.4 & 0.08 & 18.9 & 0.16 & 12.1 & 0.10 & 17.9 & 0.15 & 27.6 & 0.23 \\
\hline 180 & 8.8 & 0.05 & 16.6 & 0.09 & 11.0 & 0.06 & 11.1 & 0.06 & 25.1 & 0.14 \\
\hline 360 & 7.3 & 0.02 & 14.1 & 0.04 & 10.1 & 0.03 & 9.8 & 0.03 & 21.1 & 0.06 \\
\hline 540 & 4.5 & 0.01 & 12.7 & 0.02 & 11.5 & 0.02 & 9.0 & 0.02 & 14.4 & 0.03 \\
\hline 720 & 4.2 & 0.01 & 12.1 & 0.02 & 8.8 & 0.01 & 8.1 & 0.01 & 13.3 & 0.02 \\
\hline 1440 & 3.5 & 0.00 & 11.9 & 0.01 & 7.6 & 0.01 & 7.4 & 0.01 & 11.5 & 0.01 \\
\hline
\end{tabular}

\section{Conclusion}

We show that the physical and chemical properties of mesoporous silica materials can be modified by incorporation of an organo-sulfonic acid group by post-synthesis grafting. The successful incorporation of $\mathrm{Pr}_{-} \mathrm{SO}_{3} \mathrm{H}$ functional groups into and on the mesoporous silica materials was confirmed by XRD, nitrogen sorption and acid titration analyses. In terms of the catalytic ability, the esterification of methanol or glycerol with oleic acid using the $\mathrm{Pr}_{-} \mathrm{SO}_{3} \mathrm{H}$-functionalized mesoporous silica catalysts revealed that the heterogeneous acidic catalysts had a higher catalytic activity due to the presence of the sulfonic acid groups. Furthermore, it was observed that the substrate conversion and product yield depended not only on the acid strength, but also on the specific surface area, catalyst 
pore size and product molecular size. The rp-SBA-15-Pr- $\mathrm{SO}_{3} \mathrm{H}$ catalyst exhibited the highest catalytic activity for the esterification of oleic acid with either methanol or glycerol, and all mesoporous supports were superior to the commercial Amberlyst-15 catalyst and nonporous silica.

\section{Acknowledgements}

The authors would like to thank the Grant for International Research Integration: Chula Research Scholar, Ratchadaphiseksomphot Endowment Fund, the Postdoctoral Fellowship (Ratchadaphiseksomphot Endowment Fund) Chulalongkorn University, the Knut and Alice Wallenberg Foundation (KAW 2012.0083), and Nanolith Sverige AB for financially supporting this project.

\section{References}

[1] T.M. Suzuki, T. Nakamura, E. Sudo, Y. Akimoto, K. Yano, Micropor. Mesopor. Mater. 111 (2008) 350-358.

[2] A. Galarneau, D. Desplantier-Giscard, F. Di Renzo, F. Fajula, Catal. Today 68 (2001) 191-200.

[3] A. Taguchi, F. Schüth, Micropor. Mesopor. Mater. 77 (2005) 1-45.

[4] N. Igarashi, K.A. Koyano, Y. Tanaka, S. Nakata, K. Hashimoto, T. Tatsumi, Micropor. Mesopor. Mater. 59 (2003) 43-52.

[5] D. Zhao, J. Feng, Q. Huo, N. Melosh, G.H. Fredrickson, B.F. Chmelka, G.D. Stucky, Science 279 (1998) 548-552.

[6] J. Fan, J. Lei, L. Wang, C. Yu, B. Tu, D. Zhao, Chem. Commun. 17 (2003) 2140-2141.

[7] J. Lei, J. Fan, C. Yu, L. Zhang, S. Jiang, B. Tu, D. Zhao, Micropor. Mesopor.Mater. 73 (2004) 121-128. 
[8] J. Sun, H. Zhang, R. Tian, D. Ma, X. Bao, D.S. Su, H. Zou, Chem. Commun. 8 (2006) $1322-1324$.

[9] M. Kruk, L. Cao, Langmuir 23 (2007) 7247-7254.

[10] H. Zhang, J. Sun, D. Ma, X. Bao, A. Klein-Hoffman, G. Weinberg, D. Su, R. Schlögl, J. Am. Chem. Soc. 126 (2004) 7440-7441.

[11] H. Zhang, J. Sun, D. Ma, G. Weinberg, D.S. Su, X. Bao, J. Phys. Chem. B 110 (2006) 25908-25915.

[12] J. Sun, H. Zhang, D. Ma, Y. Chen, X. Bao, A. Klein-Hoffman, N. Pfänder, D.S. Su, Chem. Commun. (2005) 5343-5345.

[13] J. Sun, D. Ma, H. Zhang, C. Wang, X. Bao, D.S. Su, A. Klein-Hoffman, G. Weinberg, S. Mann, J. Mater. Chem. 16 (2006) 1507-1510.

[14] J. Sun, D. Ma, H. Zhang, F. Jiang, Y. Cui, R. Guo, X. Bao, Langmuir 26 (2008) 23722380.

[15] Z. Jin, X. Wang, X. Cui, Colloids Surf. A 316 (2008) 27-36.

[16] X.Y. Bao, X.S. Zhao, J. Phys. Chem. B 109 (2005) 10727-10736.

[17] A. Sayari, B. Han, Y. Yang, J. Am. Chem. Soc. 126 (2004) 14348-14349.

[18] E.M. Johansson, M.A. Ballem, J.M. Córdoba, M. Odén, Langmuir 27 (2011) 49944999.

[19] E.M. Björk, F. Söderlind, M. Odén, Langmuir 29 (2013) 13551-13561.

[20] C. Yu, J. Fan, B. Tian, D. Zhao, G.D. Stucky, Adv. Mater. 14 (2002) 1742-1745.

[21] E.M. Björk, F. Söderlind, M. Odén, J. Colloid. Interface Sci. 413 (2014) 1-7.

[22] P. Schmidt-Winkel, P. Yang, D.I. Margolese, B.F. Chmelka, G.D. Stucky, Adv. Mater. 11

(1999) 303-307.

[23] D. Zhao, J. Sun, Q. Li, G.D. Stucky, Chem. Mater. 12 (2000) 275-279. 
[24] S. Miao, B.H. Shanks, J. Catal. 279 (2011) 136-143.

[25] A. Çitak, B. Erdem, S. Erdem, R.M. Öksüzoğlu, J. Colloid. Interface Sci. 369 (2012) $160-163$.

[26] L. Sherry, J.A. Sullivan, Catal. Today 175 (2011) 471-476.

[27] A. Stein, B.J. Melde, R.C. Schroden, Adv. Mater.12 (2000) 1403-1419.

[28] K. Nakajima, I. Tomita, M. Hara, S. Hayashi, K. Domen, J.N. Kondo, Catal. Today 116

(2006) 151-156.

[29] G.J.A.A. Soler-Illia, C. Sanchez, B. Lebeau, J. Patarin, Chem. Rev. 102 (2002) 40934138.

[30] A.P. Wight, M.E. Davis, Chem. Rev. 102 (2002) 3589-3614.

[31] I.K. Mbaraka, D.R. Radu, V.S.-Y. Lin, B.H. Shanks, J. Catal. 219 (2003) 329-336.

[32] E.M. Johansson, J.M. Córdoba, M. Odén, Micropor. Mesopor. Mater. 133 (2010) 6674.

[33] K.N. Tayade, M. Mishra, J. Mol. Catal. A-Chem. 382 (2014) 114-125.

[34] S.S. Reddy, B.D. Raju, V.S. Kumar, A.H. Padmasri, S. Narayanan, K.S.R. Rao, Catal. Commun. 8 (2007) 261-266.

[35] E.M. Johansson, J.M. Córdoba, M. Odén, Mater. Lett. 63 (2009) 2129-2131.

[36] B. Rác, Á. Molnár, P. Forgo, M. Mohai, I. Bertóti, J. Mol. Catal. A-Chem. 244 (2006) 46-57.

[37] M.S. Khayoon, B.H. Hameed, Appl. Catal. A-Gen. 433-434 (2012) 152-161.

[38] Analysis software user's manual, BELSORP, BEL JAPAN, INC, 57.

[39] R. Buzzoni, S. Bordiga, G. Ricchiardi, G. Spoto, A. Zecchina, J. Phys. Chem. 99 (1995) 11937-11951. 
[40] A.S. Cattaneo, C. Ferrara, D.C. Villa, S. Angioni, C. Milanese, D. Capsoni, S. Grandi, P. Mustarelli, V. Allodi, G. Mariotto, S. Brutti, E. Quartarone, Micropor. Mesopor. Mater. 219 (2016) 219-229.

[41] G. Socrates, Infrared and Raman Characteristic Group Frequencies, third ed., John Wiley \& Sons, Chichester, 2001, pp. 209 - 228.

[42] S. Jeenpadiphat, D.N. Tungasmita, Powder Technol. 237 (2013) 634-640. 


\section{Table 1}

Physicochemical and textural properties of the propyl sulfonic acid $\left(\mathrm{Pr}-\mathrm{SO}_{3} \mathrm{H}\right)$-functionalized samples.

\begin{tabular}{|c|c|c|c|c|c|c|c|c|c|}
\hline$\overline{\text { Catalyst }}$ & $\begin{array}{l}\text { BET surface } \\
\text { area }^{\text {a }} \\
\left(\mathrm{m}^{2} / \mathrm{g}\right)\end{array}$ & $\begin{array}{l}\text { Internal } \\
\text { surface area } \\
\left(\mathrm{m}^{2} / \mathrm{g}\right)\end{array}$ & $\begin{array}{l}\text { External } \\
\text { surface area } \\
\left(\mathrm{m}^{2} / \mathrm{g}\right)\end{array}$ & $\begin{array}{l}\text { Internal/ } \\
\text { External }\end{array}$ & $\begin{array}{l}\text { Total pore } \\
\text { volume } \\
\left(\mathrm{cm}^{3} / \mathrm{g}\right)\end{array}$ & $\begin{array}{l}\text { Average pore } \\
\text { diameter }^{\mathrm{c}} \\
(\mathrm{nm})\end{array}$ & $\begin{array}{l}\mathrm{a}_{0}{ }^{\mathrm{d}} \\
(\mathrm{nm})\end{array}$ & $\begin{array}{l}\text { Wall } \\
\text { thickness }^{\mathrm{d}} \\
(\mathrm{nm})\end{array}$ & $\begin{array}{l}\text { Acid } \\
\text { amount }^{\mathrm{e}} \\
(\mathrm{mmol} / \mathrm{g})\end{array}$ \\
\hline rp-SBA-15-Pr- $\mathrm{SO}_{3} \mathrm{H}$ & 733 & 681 & 32 & 21.3 & 1.04 & 8.0 & 10.8 & 2.8 & 1.58 \\
\hline rd-SBA-15-Pr- $\mathrm{SO}_{3} \mathrm{H}$ & 303 & 187 & 143 & 1.3 & 1.15 & 10.5 & 13.1 & 2.6 & 1.54 \\
\hline f-SBA-15 & 462 & 379 & 104 & 3.6 & 1.21 & 12.1 & 13.5 & 1.4 & 0.58 \\
\hline f-SBA-15-Pr- $\mathrm{SO}_{3} \mathrm{H}$ & 387 & 313 & 93 & 3.4 & 1.07 & 10.5 & 13.1 & 2.6 & 1.28 \\
\hline MCM-41 & 954 & 918 & 40 & 23.0 & 0.89 & 2.4 & 4.7 & 2.3 & 0.54 \\
\hline Fume silica-Pr- $\mathrm{SO}_{3} \mathrm{H}$ & 158 & - & - & - & - & - & - & - & 0.15 \\
\hline
\end{tabular}

${ }^{\mathrm{a} C}$ Calculated by the BET method

${ }^{\mathrm{b}}$ Internal surface area $=($ total surface area $($ from $t$-plot $))-($ external surface area $($ from $t$-plot $))$

${ }^{\mathrm{c} C}$ Calculated by the BJH method

${ }^{\mathrm{d}}$ Wall thickness $=\left(\mathrm{a}_{0}\right)-($ pore diameter $)$, where $\mathrm{a}_{0}=2 \times d_{(100)} / \sqrt{3}, d_{(100)}=d$-spacing of the $(100)$ reflection from the XRD analysis 
${ }^{\mathrm{e}}$ Acid amount obtained by acid-base titration

${ }^{\mathrm{f}}$ Data from the suppliers (Rohm \& Haas, France) 


\section{Table 2}

The oleic acid conversion level and triglyceride (TG) yield in the esterification of a 6:1 oleic acid: glycerol molar ratio reaction catalyzed by a 5 wt. \% catalyst loading (based on total reactant weight) of propyl sulfonic acid (Pr-SO ${ }_{3} \mathrm{H}$ )-functionalized mesoporous silica or the commercial Amberlyst- 15 catalyst at $110^{\circ} \mathrm{C}$ for up to $1440 \mathrm{~min}$ of reaction time.

\begin{tabular}{|c|c|c|c|c|c|c|c|c|c|c|c|c|}
\hline \multirow{3}{*}{$\begin{array}{l}\text { Reaction } \\
\text { time } \\
(\min )\end{array}$} & \multicolumn{12}{|c|}{ Catalyst } \\
\hline & \multicolumn{2}{|c|}{ No catalyst } & \multicolumn{2}{|c|}{ Amberlyst-15 } & \multicolumn{2}{|c|}{ rp-SBA-15-Pr-SO ${ }_{3} \mathrm{H}$} & \multicolumn{2}{|c|}{ f-SBA-15-Pr- $\mathrm{SO}_{3} \mathrm{H}$} & \multicolumn{2}{|c|}{ rd-SBA-15-Pr- $\mathrm{SO}_{3} \mathrm{H}$} & \multicolumn{2}{|c|}{$\mathrm{MCM}-41-\mathrm{Pr}-\mathrm{SO}_{3} \mathrm{H}$} \\
\hline & $\begin{array}{c}\text { Oleic acid } \\
\text { conversion } \\
(\%)\end{array}$ & $\begin{array}{c}\mathrm{TG} \\
\text { yield } \\
(\%)\end{array}$ & $\begin{array}{c}\text { Oleic acid } \\
\text { conversion } \\
(\%)\end{array}$ & $\begin{array}{c}\mathrm{TG} \\
\text { yield } \\
(\%)\end{array}$ & $\begin{array}{c}\text { Oleic acid } \\
\text { conversion } \\
(\%)\end{array}$ & $\begin{array}{c}\text { TG } \\
\text { yield } \\
(\%)\end{array}$ & $\begin{array}{c}\text { Oleic acid } \\
\text { conversion } \\
(\%)\end{array}$ & $\begin{array}{c}\mathrm{TG} \\
\text { yield } \\
(\%)\end{array}$ & $\begin{array}{c}\text { Oleic acid } \\
\text { conversion } \\
(\%)\end{array}$ & $\begin{array}{c}\mathrm{TG} \\
\text { yield } \\
(\%)\end{array}$ & $\begin{array}{c}\text { Oleic acid } \\
\text { conversion } \\
(\%)\end{array}$ & $\begin{array}{c}\mathrm{TG} \\
\text { yield } \\
(\%)\end{array}$ \\
\hline 15 & - & - & 22.5 & - & 89.1 & 45.4 & 88.0 & 22.9 & 82.5 & 17.4 & 70.2 & - \\
\hline 30 & - & - & 83.3 & 3.1 & 96.6 & 50.7 & 96.6 & 40.7 & 90.4 & 24.8 & 77.3 & 3.9 \\
\hline 45 & - & - & 92.3 & 15.2 & 98.4 & 53.3 & 99.0 & 40.2 & 91.4 & 29.9 & 86.2 & 11.2 \\
\hline 60 & - & - & 99.3 & 25.8 & 99.7 & 64.3 & 64.2 & 34.4 & 98.7 & 34.2 & 91.5 & 13.2 \\
\hline 120 & 9.3 & - & 96.9 & 44.4 & 97.7 & 31.2 & 55.3 & 33.9 & 88.8 & 37.8 & 96.4 & 14.7 \\
\hline 180 & 16.9 & 0.4 & 89.4 & 37.9 & 86.5 & 30.3 & 49.4 & 29.8 & 54.7 & 22.8 & 90.9 & 21.6 \\
\hline 360 & 22.9 & 1.1 & 69.3 & 20.1 & 72.6 & 29.6 & 44.7 & 25.6 & 47.8 & 21.1 & 81.2 & 30.5 \\
\hline 540 & 25.2 & 1.9 & 43.1 & 20.0 & 65.1 & 28.9 & 47.4 & 24.8 & 44.6 & 20.9 & 50.4 & 15.7 \\
\hline 720 & 32.9 & 2.5 & 40.2 & 17.9 & 61.4 & 27.3 & 33.8 & 15.3 & 40.7 & 19.7 & 46.4 & 13.8 \\
\hline 1440 & 72.8 & 14.3 & 31.5 & 11.3 & 60.5 & 27.1 & 27.5 & 10.6 & 36.9 & 18.1 & 40.0 & 11.3 \\
\hline
\end{tabular}

Data are shown as the mean $\pm 1 \mathrm{SD}$, derived from three independent repeats. 


\section{Table 3}

The turnover number (TON) and turnover frequency (TOF) from the esterification of a 6:1

oleic acid: glycerol molar ratio reaction catalyzed by a 5 wt. \% catalyst loading (based on total reactant weight) of propylsulfonic acid $\left(\mathrm{Pr}-\mathrm{SO}_{3} \mathrm{H}\right)$-functionalized mesoporous silica or the commercial Amberlyst- 15 catalyst at $110^{\circ} \mathrm{C}$ for up to 1440 min of reaction time.

\begin{tabular}{|c|c|c|c|c|c|c|c|c|c|c|}
\hline \multirow{4}{*}{$\begin{array}{l}\text { Reaction } \\
\text { time } \\
(\mathrm{min})\end{array}$} & \multicolumn{10}{|c|}{ Catalyst } \\
\hline & \multicolumn{2}{|c|}{ Amberlyst-15 } & \multicolumn{2}{|c|}{ rp-SBA-15-Pr-SO ${ }_{3} \mathrm{H}$} & \multicolumn{2}{|c|}{ f-SBA-15-Pr- $\mathrm{SO}_{3} \mathrm{H}$} & \multicolumn{2}{|c|}{ rd-SBA-15-Pr- $\mathrm{SO}_{3} \mathrm{H}$} & \multicolumn{2}{|c|}{ MCM-41-Pr-SO ${ }_{3} \mathrm{H}$} \\
\hline & TON & TOF & TON & TOF & TON & TOF & TON & TOF & TON & TOF \\
\hline & & $\left(\min ^{-1}\right)$ & & $\left(\min ^{-1}\right)$ & & $\left(\min ^{-1}\right)$ & & $\left(\min ^{-1}\right)$ & & $\left(\min ^{-1}\right)$ \\
\hline 15 & 3.9 & 0.26 & 19.0 & 1.26 & 28.4 & 1.89 & 24.1 & 1.61 & 23.4 & 1.56 \\
\hline 30 & 11.4 & 0.38 & 19.7 & 0.66 & 24.9 & 0.83 & 23.3 & 0.78 & 24.6 & 0.82 \\
\hline 45 & 10.5 & 0.23 & 19.5 & 0.43 & 23.7 & 0.53 & 21.7 & 0.48 & 26.1 & 0.58 \\
\hline 60 & 10.4 & 0.17 & 17.3 & 0.29 & 15.4 & 0.26 & 22.9 & 0.38 & 26.9 & 0.45 \\
\hline 120 & 9.4 & 0.08 & 18.9 & 0.16 & 12.1 & 0.10 & 17.9 & 0.15 & 27.6 & 0.23 \\
\hline 180 & 8.8 & 0.05 & 16.6 & 0.09 & 11.0 & 0.06 & 11.1 & 0.06 & 25.1 & 0.14 \\
\hline 360 & 7.3 & 0.02 & 14.1 & 0.04 & 10.1 & 0.03 & 9.8 & 0.03 & 21.1 & 0.06 \\
\hline 540 & 4.5 & 0.01 & 12.7 & 0.02 & 11.5 & 0.02 & 9.0 & 0.02 & 14.4 & 0.03 \\
\hline 720 & 4.2 & 0.01 & 12.1 & 0.02 & 8.8 & 0.01 & 8.1 & 0.01 & 13.3 & 0.02 \\
\hline 1440 & 3.5 & 0.00 & 11.9 & 0.01 & 7.6 & 0.01 & 7.4 & 0.01 & 11.5 & 0.01 \\
\hline
\end{tabular}




\section{Figure captions}

Fig. 1. Representative XRD patterns of mesoporous silica and propyl sulfonic-functionalized mesoporous silica samples.

Fig. 2. Representative $\mathrm{N}_{2}$ adsorption/desorption isotherms of mesoporous silica and propyl sulfonic-functionalized mesoporous silica samples.

Fig. 3. Representative FT-IR spectra of the (a) rp-SBA-15, (b) rp-SBA-15-Pr-SO ${ }_{3} \mathrm{H}$, (c) rdSBA-15-Pr-SO ${ }_{3} \mathrm{H}$, (d) f-SBA-15-Pr- $\mathrm{SO}_{3} \mathrm{H}$ and (e) MCM-41-Pr-SO ${ }_{3} \mathrm{H}$ samples, in the spectral region of $400-2000 \mathrm{~cm}^{-1}$.

Fig. 4. Representative SEM images (20,000 × magnification) of (a) rp-SBA-15, (b) rd-SBA-15, (c) f-SBA-15, (d) MCM-41 and TEM images of (e) rp-SBA-15-Pr-SO ${ }_{3} \mathrm{H}$, (f) rd-SBA-15-Pr$\mathrm{SO}_{3} \mathrm{H}$, (g) f-SBA-15-Pr-SO${ }_{3} \mathrm{H}$ and (h) MCM-41-Pr- $\mathrm{SO}_{3} \mathrm{H}$.

Fig. 5. Time course of the esterification of a 1:9 molar ratio of oleic acid: methanol at $60^{\circ} \mathrm{C}$ for $15-180$ min with 0.5 wt.\% of the different propyl sulfonic acid $\left(\mathrm{Pr}_{-} \mathrm{SO}_{3} \mathrm{H}\right)$-functionalized mesoporous silica catalysts or the commercial Amberlyst-15 one, compared to that without a catalyst. 


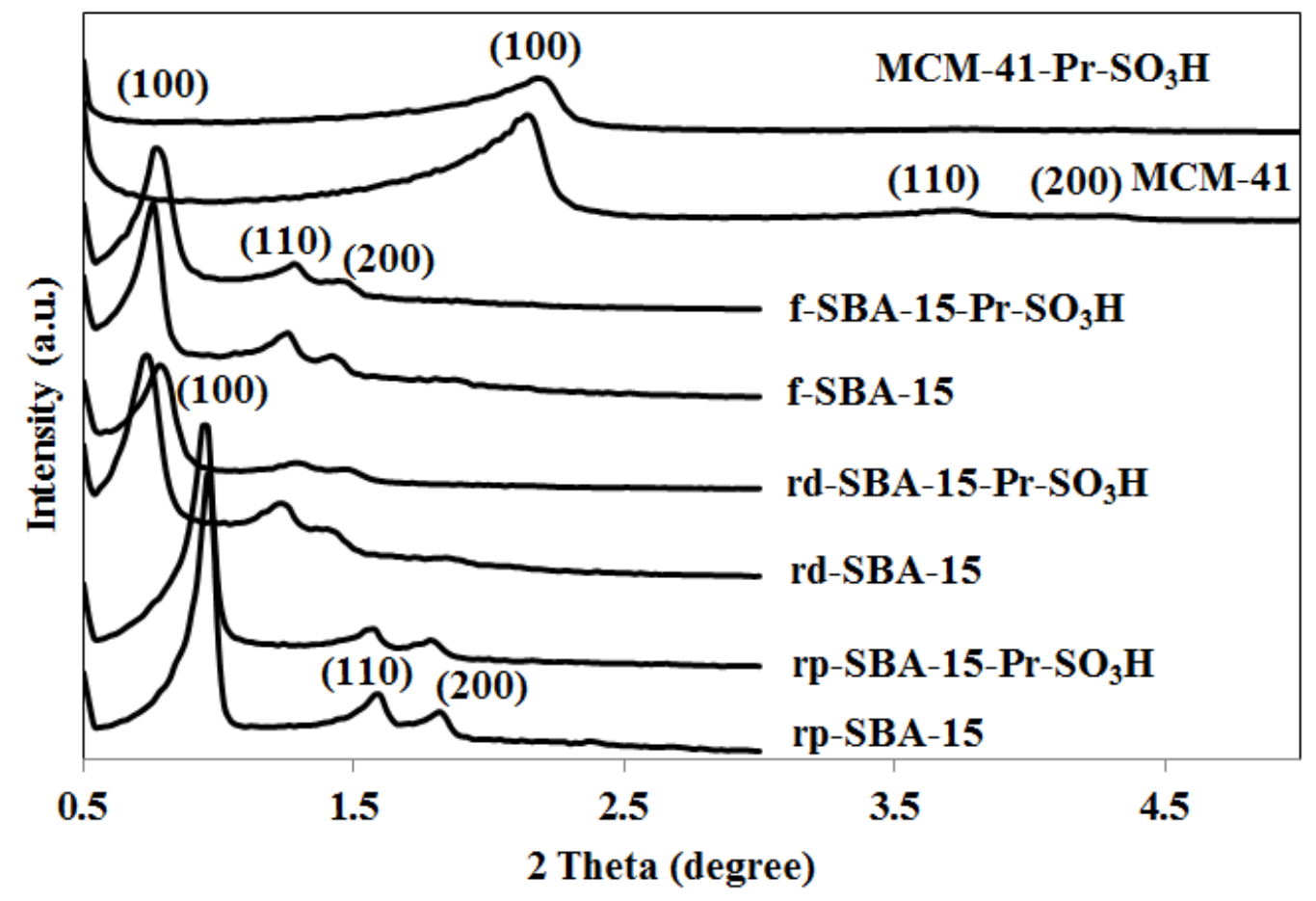

Fig. 1. 


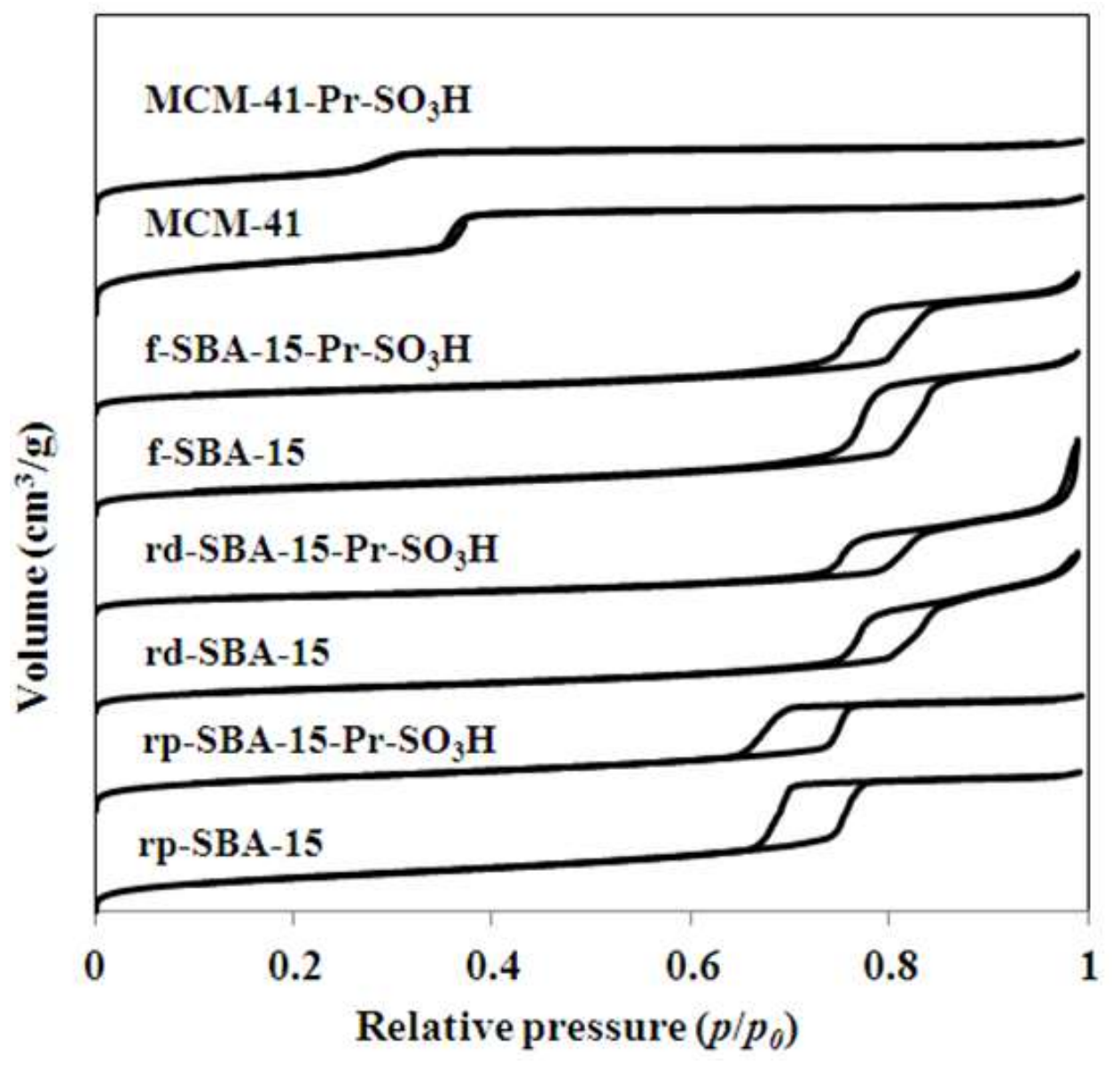

Fig. 2. 


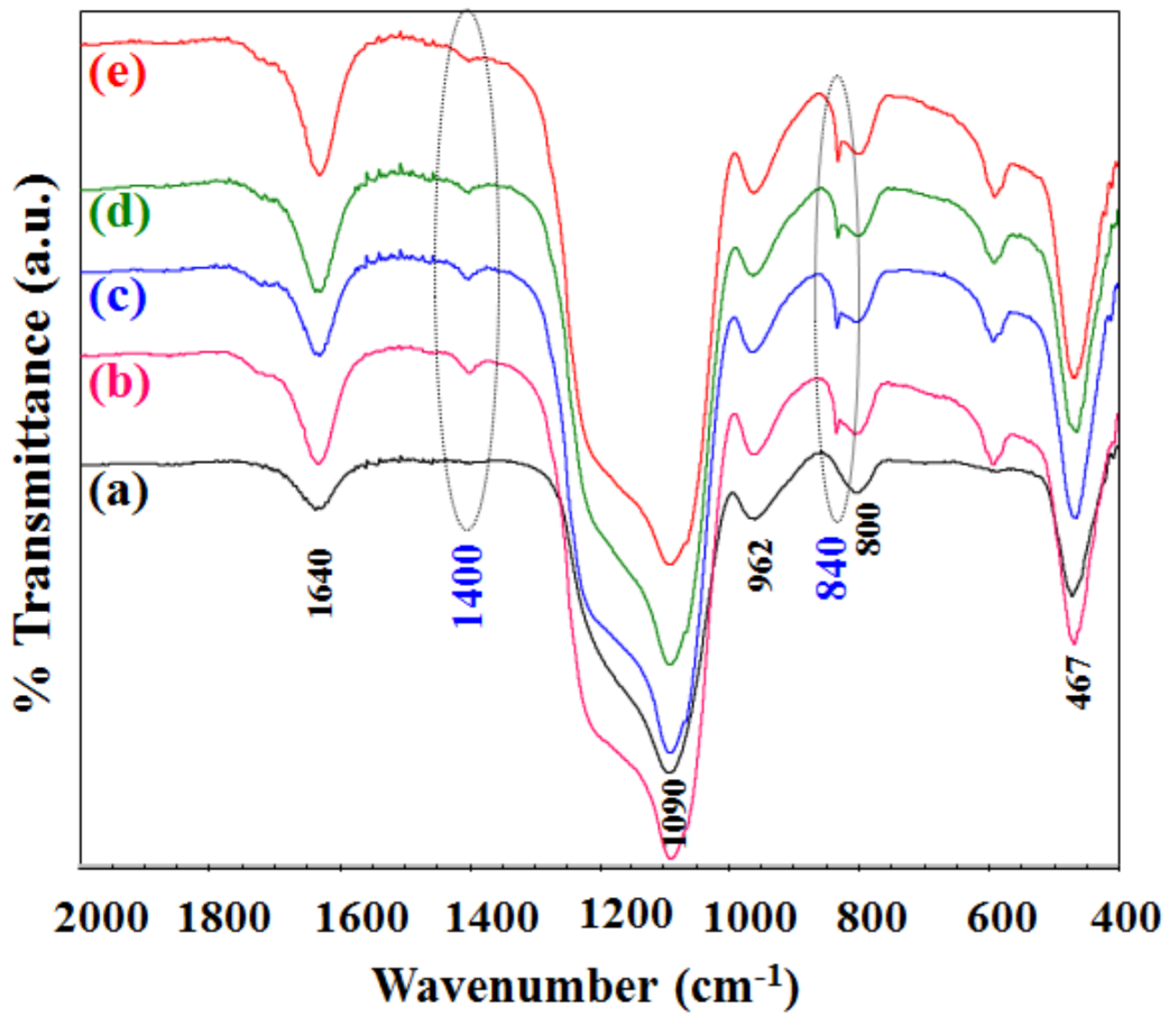

Fig. 3. 

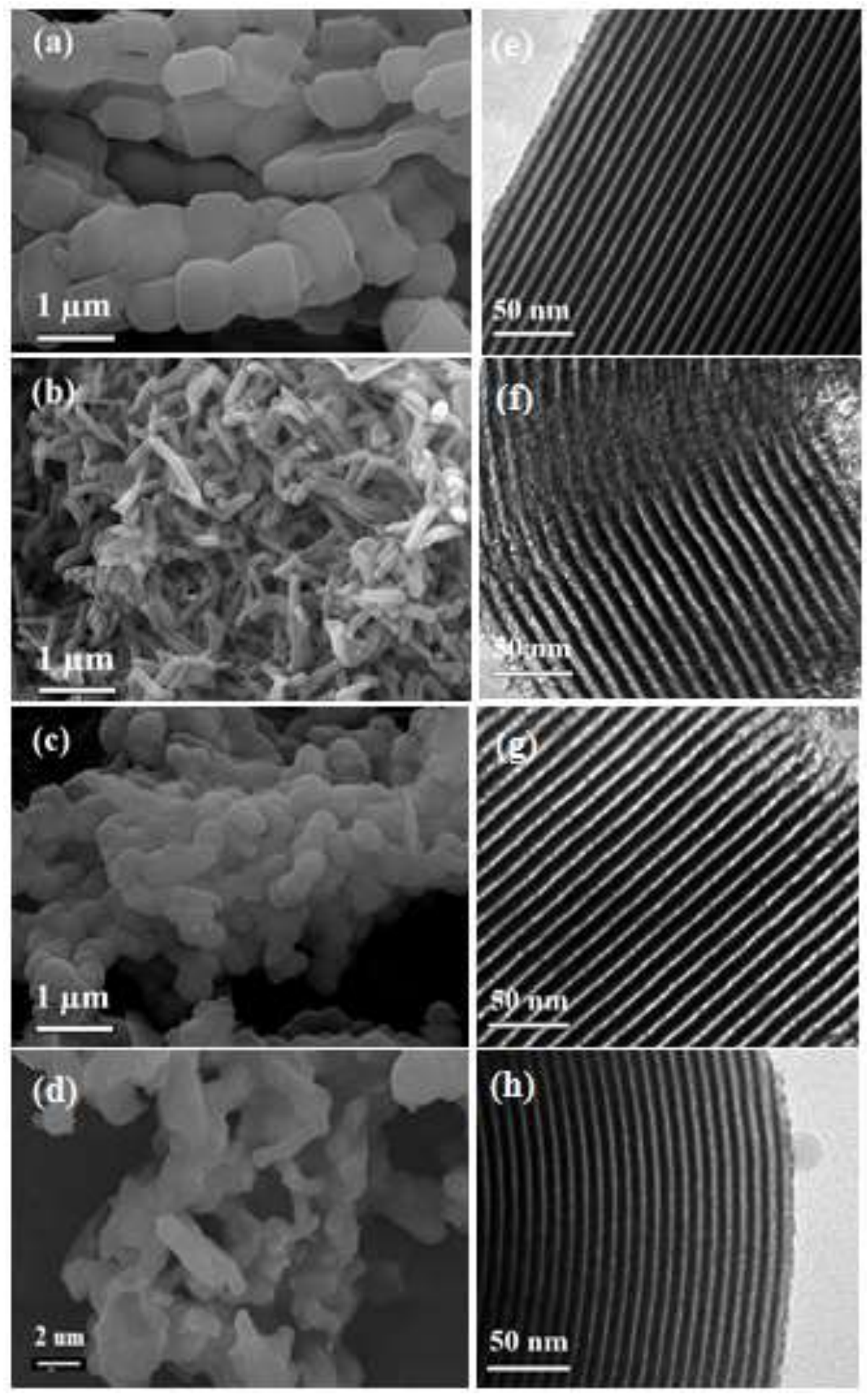

Fig. 4. 


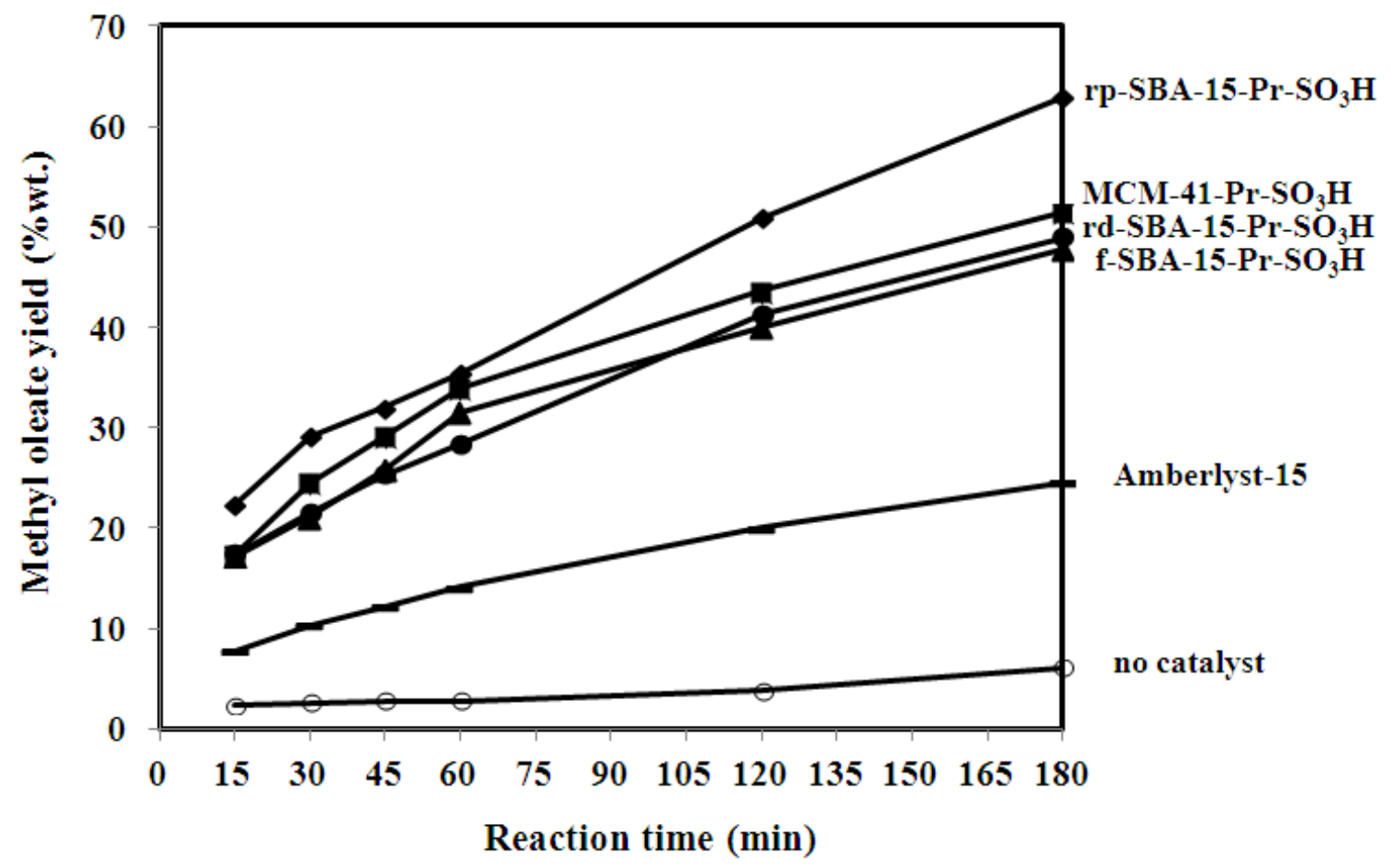

Fig. 5. 


\section{Supplementary information}

\section{Table S1}

The oleic acid conversion level and MG, DG and TG yield from the esterification of a 6:1 oleic acid: glycerol molar ratio reaction catalyzed by a 5 wt. \% of rp-SBA-15-Pr-SO ${ }_{3} \mathrm{H}-$ functionalized catalyst (based on total reactant weight) at $110{ }^{\circ} \mathrm{C}$ for up to $24 \mathrm{~h}$ of reaction time.

\begin{tabular}{ccccc}
\hline Reaction time & Oleic acid & \multicolumn{3}{c}{ Yield (wt.\%) } \\
\cline { 3 - 5 }$(\min )$ & conversion $(\%)$ & MG & DG & TG \\
\hline 15 & 89.1 & 23.6 & 20.0 & 45.4 \\
30 & 96.6 & 20.7 & 25.3 & 50.7 \\
45 & 98.4 & 17.9 & 27.1 & 53.3 \\
60 & 99.7 & 5.9 & 29.5 & 64.3 \\
120 & 97.7 & 5.7 & 60.8 & 31.2 \\
180 & 86.5 & 5.6 & 50.6 & 30.3 \\
360 & 72.6 & 7.3 & 35.7 & 29.6 \\
540 & 65.1 & 7.9 & 28.2 & 28.9 \\
720 & 61.4 & 7.9 & 26.1 & 27.3 \\
1,440 & 60.5 & 8.2 & 25.3 & 27.1 \\
\hline
\end{tabular}




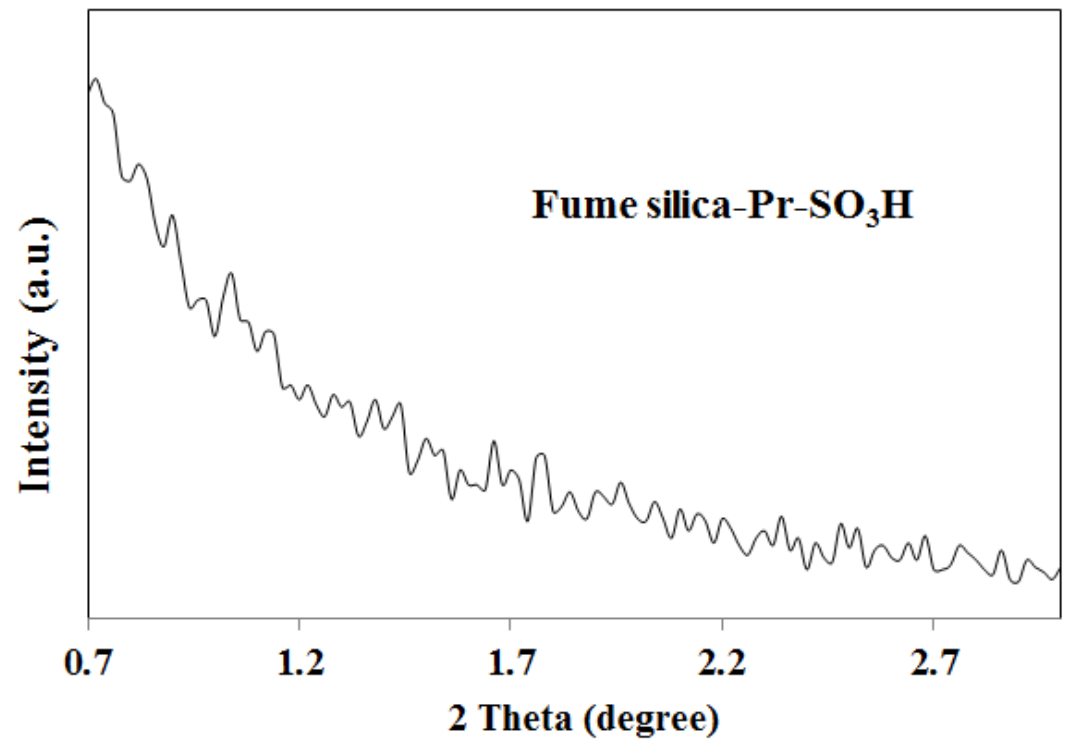

Fig. S1. Representative XRD pattern of propyl sulfonic-functionalized non-porous fume silica sample. 


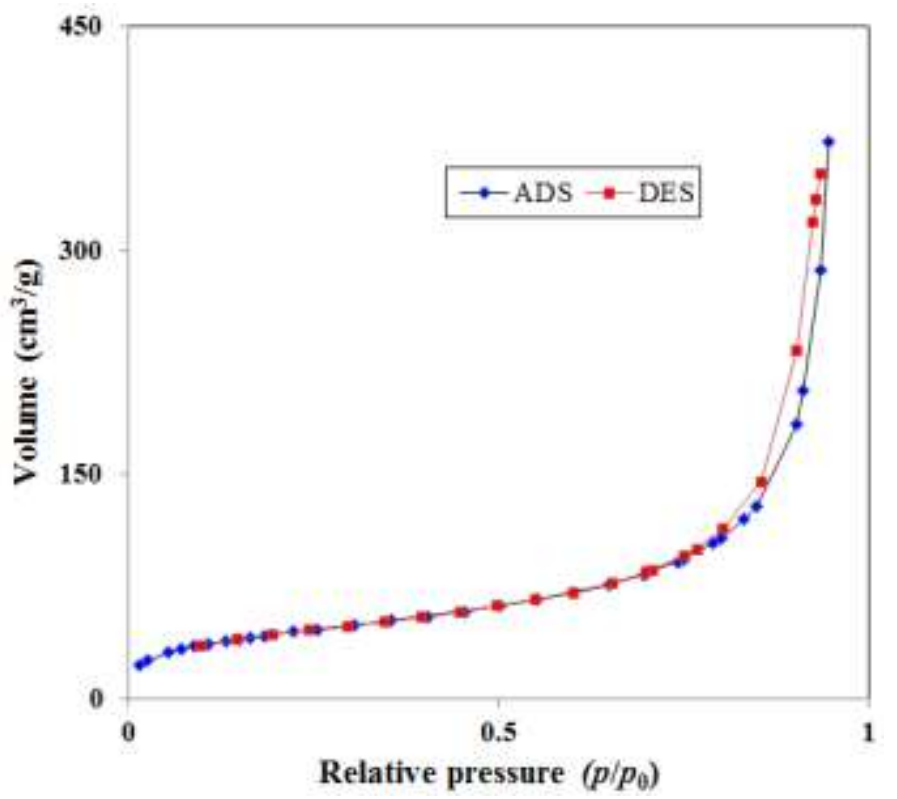

Fig. S2. Representative $\mathrm{N}_{2}$ adsorption/desorption isotherms of propyl sulfonic-functionalized non-porous fume silica sample. 